Review

\title{
Catalysts Supported on Carbon Materials for the Selective Hydrogenation of Citral
}

\section{Esther Bailón-García *, Francisco J. Maldonado-Hódar, Agustín F. Pérez-Cadenas and Francisco Carrasco-Marín}

Carbon Materials Research Group, Department of Inorganic Chemistry, Faculty of Sciences, University of Granada, Campus Fuentenueva s/n, 18071 Granada, Spain;

E-Mails: fjmaldon@ugr.es (F.J.M.-H.); afperez@ugr.es (A.F.P.-C.); fmarin@ugr.es (F.C.-M.)

* Author to whom correspondence should be addressed; E-Mail: estherbg@ugr.es;

Tel.: +34-958-243-235; Fax: +34-958-248-526.

Received: 14 August 2013; in revised form: 22 September 2013 / Accepted: 11 October 2013 /

Published: 22 October 2013

\begin{abstract}
The heterogeneously catalyzed selective-hydrogenation of citral is one of the more feasible ways for obtaining its appreciated unsaturated-alcohols, nerol and geraniol, which are present in over 250 essential oils. Thus, citral has very recently come to be produced petro-chemically in very large quantities, and so partial hydrogenation of citral has become a very economical route for the production of these compounds. However, the selective hydrogenation of citral is not easy, because citral is an $\alpha, \beta$-unsaturated aldehyde which possesses three double bonds that can be hydrogenated: an isolated $\mathrm{C}=\mathrm{C}$ bond and the conjugated $\mathrm{C}=\mathrm{O}$ and $\mathrm{C}=\mathrm{C}$ bonds. For this reason, in catalyst selection there are several important issues which affect the product selectivity, for example, the active metal and metal particle size which are factors related to the catalyst preparation method, catalyst precursor, or support surface area, as well as other factors such as porosity, the addition of a second catalytic metal, and, of course, the type of catalyst support. About this last one, carbon materials are very interesting supports for this type of hydrogenation reaction due to their unique chemical and textural properties. This review collects and analyzes the results obtained in the selective hydrogenation of citral catalyzed by carbon material supported metals.
\end{abstract}

Keywords: citral; hydrogenation; activated carbon; graphite; carbon nanotubes 


\section{Introduction}

Since ancient times, essential oils and extracts have been used for many different applications such as perfumes, air fresheners, cosmetics and medicinal substances. These compounds were mainly extracted by steam distillation or solvent extraction of different vegetable raw materials. These essential oils consist primarily in terpenes, where their unsaturated alcohols play a very important role. In particular, nerol and geraniol are present in over 250 essential oils as ninde oil (66.3\%) [1], rose oil $(59.0 \%)$ [2], palmarosa oil (80.9\% geraniol in leaf) [3], monarda fistulosa oil (>95\%) [4], citronella oil (24.8\%) [5], among other essential oils.

Geraniol was isolated from palmarosa oil while nerol was obtained from the oil of neroli $[6,7]$. These monoterpenes are widely used in fragrance and flavour industries. A survey of consumer products between 1996-2001 revealed that they are present in 76\% of 73 investigated deodorants on the European market-95\% in vapo-spray deodorants, $91 \%$ in aerosol sprays deodorants and $46 \%$ in roll-on deodorants [8] — in the $41 \%$ of 59 investigated domestic and occupational products [9], and in the $33 \%$ of cosmetic formulations [10], their production in that year being more than 1000 metric tons [11]. In addition, recent studies revealed that geraniol exhibits various biochemical and pharmacological properties as a potential antimicrobial agent [12], an effective plant based insect repellent (currently being marketed by Fulltec ${ }^{\circledR}$ and BugBand ${ }^{\circledR}$, for example) [13-15], an anti-inflammatory [16], anthelmintic [17,18], anti-oxidant [19,20] and anti-herpetic agent [21], and furthermore, geraniol exerts in vitro and in vivo antitumor activity against murine leukemia, hepatoma and melanoma cells [22-26]. Furthermore, this molecule is an important intermediate in the synthesis of other organic molecules with high added value [27] such as phellandrene, myrcene, ocimene, linalool and vitamins A and E [28].

This increase in the use of geraniol and nerol makes necessary a chemical synthesis of this compound. Actually, the industrial production of these compounds is mainly done from $\beta$-pinene by companies such as International Flavors and Fragrances (IFF), Pinova, DRT and TECNAL Corporation [29,30]. This process [31], shown in Figure 1, involves the pyrolysis of $\beta$-pinene, which yields $90 \%$ myrcene by passing it through a tube at $550-600{ }^{\circ} \mathrm{C}$ with a very short contact time. Then, in a second step (myrcene hydrochlorination), hydrogen chloride is added to myrcene in the presence of a small amount of cuprous chloride catalyst and an organic quaternary ammonium salt to effect a preferential addition at the allylic double bond resulting in the formation of a higher proportion of geranyl or neryl chloride, linalyl chloride and a little myrcenyl chloride. After removal of the catalyst, the crude mixture of chlorides is converted to a mixture of acetates (or formates) by addition of sodium acetate or sodium formate with a phase-transfer catalyst (PTC) or in the presence of a nitrogen base to give predominantly geranyl acetate $(50 \%-55 \%)$, neryl acetate $(40 \%-50 \%)$ and small amount of linalyl acetate. Saponification of the acetates or formates gives the corresponding alcohols and the sodium acetate or formate which is recycled. Fractionation of the crude alcohol mixture gives both geraniol and nerol products, usually as mixtures. Further fractional distillation yields about $98 \%$ geraniol $[30,31]$. 
Figure 1. Industrial-scale production process of nerol and geraniol. Powered by International Flavors and Fragrances (IFF), Pinova, and Dérivés Tecnal Résiniques et Terpéniques (DRT). Adapted from [31].

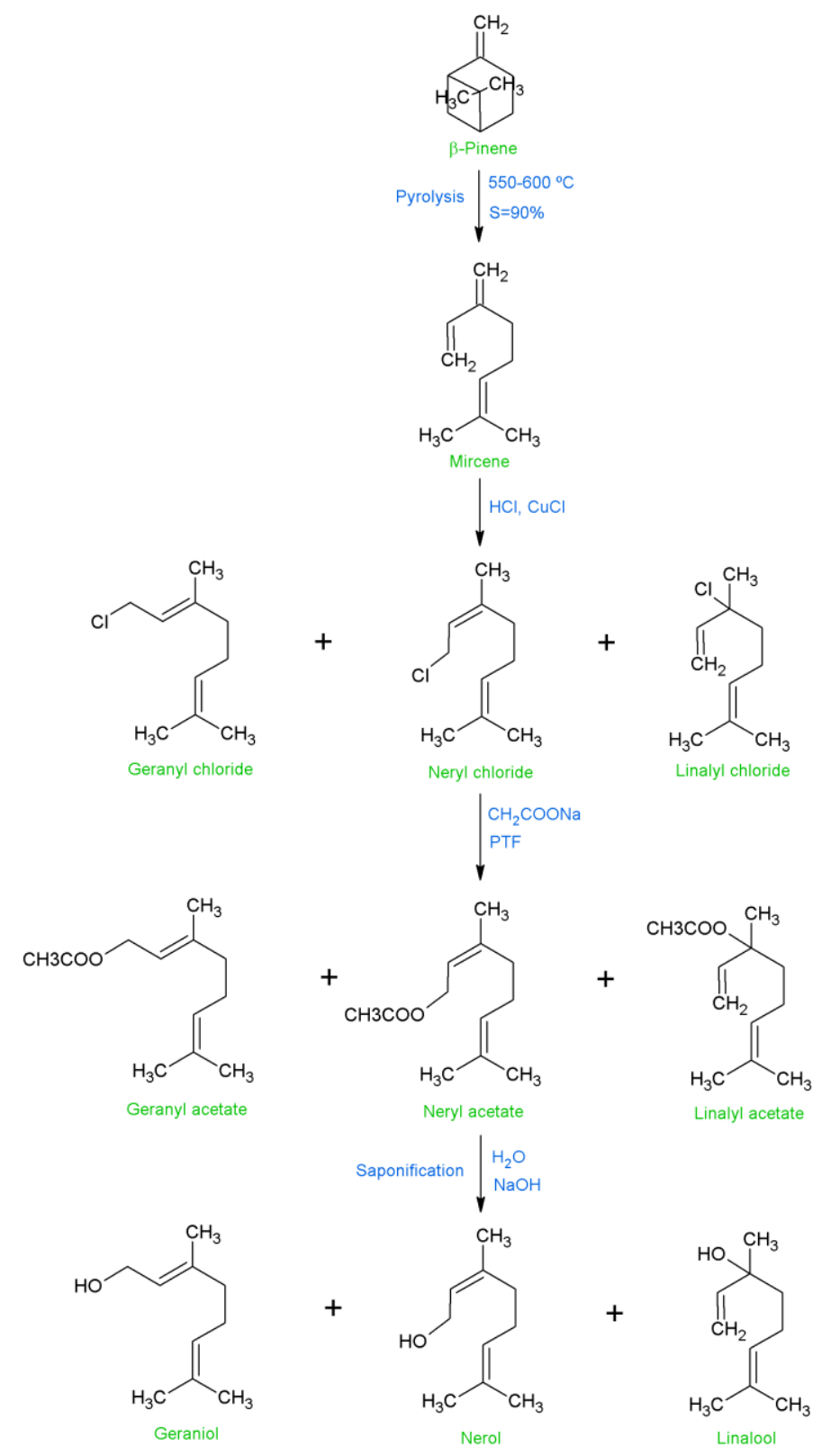

The drawback of the industrial manufacturing process is the multitude of needed stages, including a pyrolysis, with the difficulties that it entails the need of large amount of reagents, and the corresponding loss of performance of each stage. For these reasons, the selective hydrogenation of citral is one of the more feasible ways for obtaining these unsaturated alcohols being a single step synthesis. Furthermore, citral has very recently come to be produced petrochemically in very large quantities, and so partial hydrogenation of citral has become a very economical route for the production of geraniol and nerol [31]. Therefore, the hydrogenation of citral is attracting the attention of a large number of scientists worldwide. Citral (3,7-dimethyl-2,6-octadienal) is a monoterpene found in plants and citrus fruits. It is an isomeric mixture of the acyclic aldehydes geranial (citral E) and neral (citral Z). 
On the other hand, carbon materials show several advantages when they are used as supports in heterogeneous catalysis and especially in hydrogenation reactions [32]:

(i) Carbon surface is relatively inert, preventing the occurrence of unwanted reactions catalyzed by the support surface or reaction of the support with the active phase.

(ii) The cost of conventional carbon materials is lower than other conventional supports.

(iii) Carbon materials may be obtained in different forms (granules, pellets, fibers, foams, monoliths, fabrics, coatings, etc.).

(iv) The active phase, usually expensive, can be easily recovered by simple calcination of the support.

(v) They have a high surface area and its porous framework can be modified to obtain the pore size distribution (PSD) optimum for each particular reaction.

(vi) They are stable at high temperatures in non-oxidizing atmospheres (even above $700{ }^{\circ} \mathrm{C}$ ).

(vii) Although carbon is usually a material with a hydrophobic nature, the chemical nature of their surface can be modified chemically to give them some hydrophilicity.

Despite all these advantages, carbon materials are not the main supports studied in the hydrogenation of citral as derived from the reviewed literature, being these mentioned only in $17 \%$ of the reviewed literature, and mainly they are used as reference materials. Within the carbon materials, the classical materials have been the most studied in the selective hydrogenation of citral (activated carbons and graphite were studied in the $57 \%$ and $19 \%$ of the citations, respectively). However, nowadays non-traditional carbon materials such as carbon nanotubes are widely being studied for this application ( $21 \%$ of the reviewed literature), and finally some works using advanced composite materials like Carbon- $\mathrm{TiO}_{2}$ can also be found. Although carbon xerogels and aerogels are very interesting carbon materials especially as catalyst supports [33-37], we have not found works in the reviewed literature where they have been used in the selective hydrogenation of citral. Moreover, only a few works mention these materials for the hydrogenation of $\alpha, \beta$ unsaturated aldehydes [38-40].

Finally, it should be mentioned that in the catalyst selection for the citral hydrogenation, there are several important issues which affect the product selectivity, such as the active metal [41-44], the metal-particle size [43,45-47], the support material or the use of bimetallic catalysts [45,48-50], as well as other factors relating to the operating conditions as the used solvent, which is important in the formation of acetals, the stirring, the operation temperature and pressure as well as the initial concentrations.

In this review, a widely used explanation about the different and possible reaction routes during the hydrogenation of citral, as well as a deep review of the role in the activity and selectivity of the main transition metal as catalyst in this reaction are shown. The more significant results using carbon materials, as catalyst supports in the selective hydrogenation of citral, have been collected. These results are shown and discussed by type of material, and finally, some challenges for the future are proposed.

\section{Hydrogenation Selectivity}

The selective hydrogenation of citral to nerol and geraniol is not easy, because citral is an $\alpha, \beta$ unsaturated aldehyde which possesses three double bonds that can be hydrogenated: an isolated $\mathrm{C}=\mathrm{C}$ 
bond in addition of the conjugated bonds $\mathrm{C}=\mathrm{O}$ and $\mathrm{C}=\mathrm{C}$. A completed reaction scheme is shown in Figure 2. Thermodynamics favors hydrogenation of the $\mathrm{C}=\mathrm{C}$ over the $\mathrm{C}=\mathrm{O}$ bond [51], and for kinetic reasons, the $\mathrm{C}=\mathrm{C}$ bond is more reactive than the $\mathrm{C}=\mathrm{O}$ group [51]. Therefore, in the presence of most of the monometallic catalysts based on VIII group elements, the saturated aldehyde or alcohol is obtained [52,53]. Consequently, the challenge is to selectively enhance the hydrogenation of the $\mathrm{C}=\mathrm{O}$ bond to produce nerol and geraniol, decreasing in parallel the hydrogenation of the corresponding conjugated $\mathrm{C}=\mathrm{C}$ bond reducing the formation of citronellal, and what is even more difficult, to avoid consecutives hydrogenations to single unsaturated or saturated alcohol (citronellol and 3,7 dimethyloctanol, respectively), as well as to avoid cyclization routes which produces isopulegol and its saturated alcohol menthol. Finally, other undesired reactions can take place with the use of some reaction media, such as alcohols, which can create citronellal acetals. Therefore, a highly selective hydrogenation process to nerol and geraniol can only be achieved with an optimal design of the catalyst. Nowadays, the more extended proposal for this goal turn around to activate the adsorption modes of $\mathrm{C}=\mathrm{O}$ group and/or prevent the adsorption modes of $\mathrm{C}=\mathrm{C}$ group [54]. In this way, Figure 3 shows the different adsorption modes of the molecule of citral [55].

Figure 2. Reaction scheme of the citral hydrogenation. Adapted from [56].

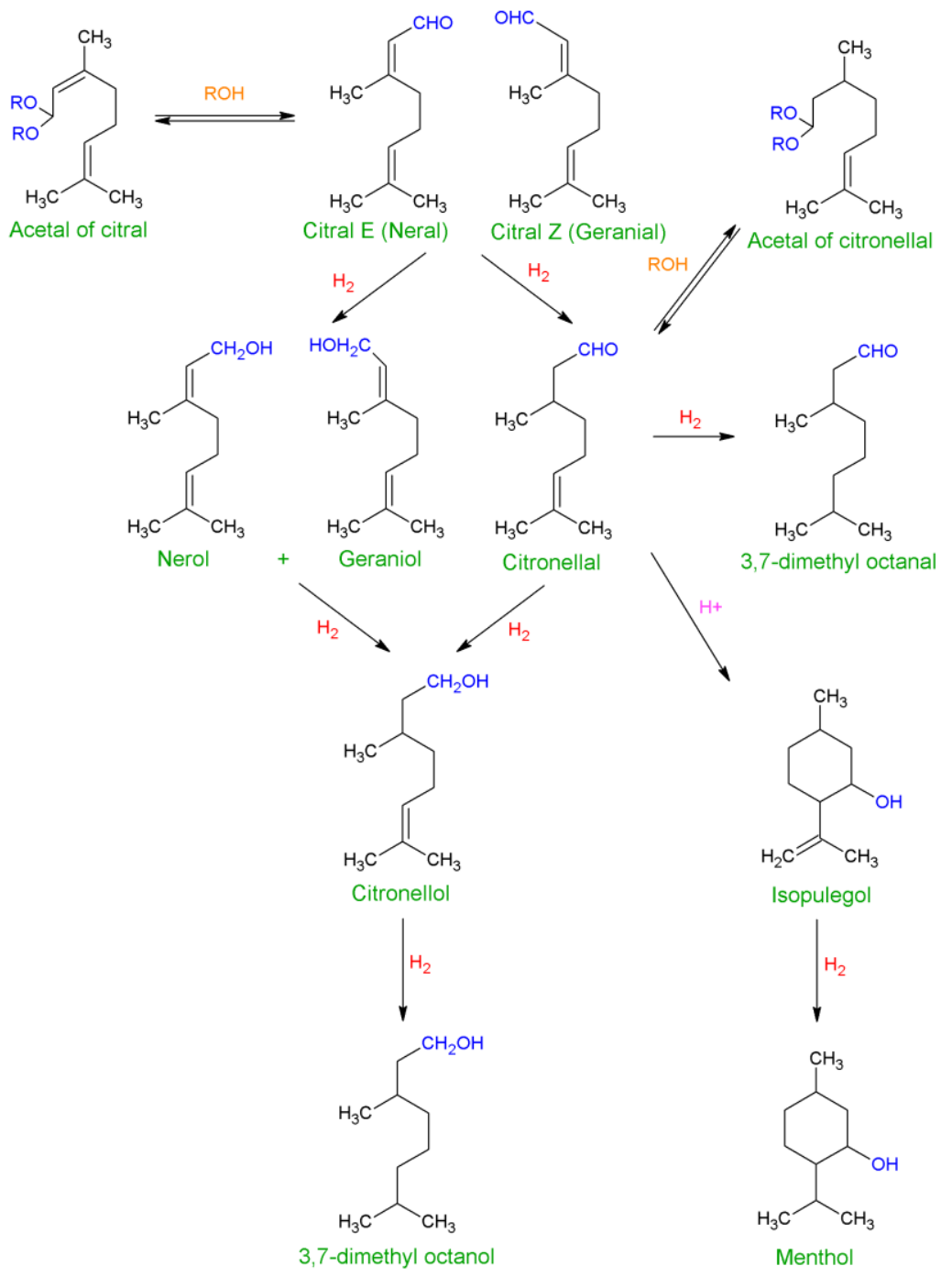


Figure 3. Adsorption modes of the $\alpha, \beta$-unsaturated aldehyde molecule. Adapted from [55].

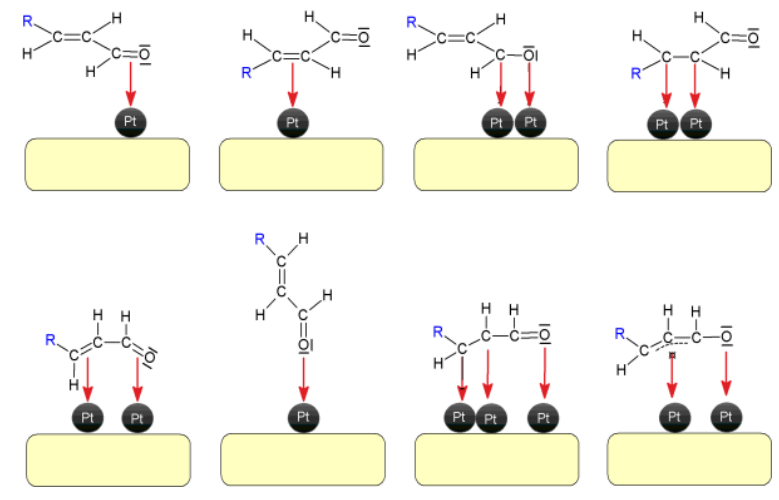

The knowledge of the adsorption modes is very important for understanding the selectivity of the hydrogenation of the $\alpha, \beta$-unsaturated aldehydes. Basically, there are three basic ways to obtain the hydrogenation of the $\mathrm{C}=\mathrm{O}$ bond and, hence, the desired unsaturated alcohol: (i) the first is to hinder the $\mathrm{C}=\mathrm{C}$ molecular adsorption. This hindrance can be achieved by an increase of the repulsive electron interactions with the surface using metals with more extended d-orbitals like osmium or iridium, or increasing the $\{111\}$ face presence in the metal surface, and finally, also using an electronically dense surface by means of an active support (i.e., graphite). (ii) The second way is to favor the interaction of the $\mathrm{C}=\mathrm{O}$ bond with the surface using Lewis acid promoters as for example the partially reducible oxides $\mathrm{TiO}_{2}$ or $\mathrm{CeO}_{2}$ in which new acid Lewis sites can be created by oxygen vacancies. (iii) The third way is a combination of both mentioned strategies, favoring the $\mathrm{C}=\mathrm{O}$ adsorption and hindering the $\mathrm{C}=\mathrm{C}$ adsorption at the same time. This would be achieved combining satisfactory electropositive and electronegative metals which produces a charge transfer between they that favors the electronic repulsion against the $\mathrm{C}=\mathrm{C}$ adsorption, being equally created polarized sites $\delta^{+}-\delta^{-}$that favor the interaction with the $\mathrm{C}=\mathrm{O}$ bond [57].

Also, other factors relating to the catalytic system should be considered such as the solvent. The solvent is important not only for preventing the formation of acetals, but also because it could affect the selectivity and the hydrogenation rates. Generally, the higher the polarity of the solvent, the higher is the hydrogenation rates, due to an increase of the $\mathrm{H}_{2}$ solubility in the solvent [58-60]. Related to the product distribution, some authors have obtained a trend modifying the polarity of the solvent. Polar solvents activated the $\mathrm{C}=\mathrm{O}$ hydrogenation whereas non-polar solvents favored the $\mathrm{C}=\mathrm{C}$ bond hydrogenation over non acidic catalysts to avoid the acetals formation over alcohol solvents $[59,61,62]$. Additionally, supercritical $\mathrm{CO}_{2}$ has been used as non-conventional solvent due to its important benefits such as: (i) the higher solubility of hydrogen than conventional solvents; (ii) much easier separation after reaction; (iii) and the improvement of selectivity in the $\mathrm{C}=\mathrm{O}$ hydrogenation. The higher selectivity towards the unsaturated alcohols using supercritical $\mathrm{CO}_{2}$ has been ascribed to specific interactions between $\mathrm{CO}_{2}$ and the citral molecules [63-65].

Another way to favor the $\mathrm{C}=\mathrm{O}$ interaction with the catalyst may be achieved by adding a water film to the surface of the catalysts. In this sense, Jiang et al. [66] used a combination of $\mathrm{Ru} / \mathrm{AlO}(\mathrm{OH})$ and water improving the catalyst activity and its selectivity to geraniol and nerol. The interactions between water molecules and the surface hydroxyl groups of the support made possible a water film adhesion around the catalyst particles. This water favoured the citral adsorption throughout the $\mathrm{C}=\mathrm{O}$ bond due to 
its more polarized bond character. In a similar way, with SLPC (supported liquid-phase catalyst) the selectivity towards the unsaturated alcohols can be modified adding water (or another polar solvent) to an organic media $[67,68]$. The drawback of this type of methodology is that the entire surface should be covered by water in order to maintain the desired selectivity [67].

\section{The Type of Transition Metal as Catalytic Phase}

In the hydrogenation of $\alpha, \beta$-unsaturated aldehydes, usually transition metals supported on oxides or carbon materials are used as catalysts. The selection of the catalytic phase is very important due to its influence on the product's selectivity. In general, Ir and Os catalysts show moderately high selectivities to $\mathrm{C}=\mathrm{O}$ hydrogenation, while $\mathrm{Pt}, \mathrm{Ru}$ and Co possess moderate selectivities and $\mathrm{Pd}, \mathrm{Rh}$ and $\mathrm{Ni}$ are unselective or poorly selective to the un-saturated alcohol. These trends were confirmed by Sokolskii et al. [69,70] in the crotonaldehyde hydrogenation with catalysts supported on carbon finding the following selectivity trend to the un-saturated alcohol: $\mathrm{Os}>\mathrm{Ir}>\mathrm{Ru}>\mathrm{Rh} \approx \mathrm{Pt} \approx \mathrm{Pd}$, and also by Giroir-Fendler et al. [41] in the hydrogenation of cinnamaldehyde using coal and graphite as supports finding the trend $\mathrm{Ir}>\mathrm{Pt}>\mathrm{Ru}>\mathrm{Rh}>\mathrm{Pd}$ with both supports. This increase of selectivity is attributed to an electronic effects according to theoretical calculations of Delbecq and Soutet and semi-empirical calculations of Hückel [54,57]. According to these authors, the selectivity to the unsaturated alcohol can be correlated with the metal d-band width. With increasing electron density and, hence, d-orbital population, the repulsive four electron interaction of the $\mathrm{C}=\mathrm{C}$ double bond with the metal surface increases, however, the interaction of the metal surface with the $\mathrm{C}=\mathrm{O} \pi$-system is favored [52,55]. Thus, the binding of unsaturated molecules on metal surfaces is based on the distinction between stabilizing two-electron (of the $\mathrm{C}=\mathrm{O}$ ) and destabilizing four-electron interactions (of the $\mathrm{C}=\mathrm{C}$ ) [71]. The $\mathrm{C}=\mathrm{C}$ coordination is very sensitive to Pauli repulsion with the surface. A metal with more diffuse orbitals will increase the Pauli repulsion and therefore weaken the $\mathrm{C}=\mathrm{C}$ adsorption. This is the case of $\mathrm{Ru}$ and Os which have a large radial expansion of the d orbitals and therefore give a good selectivity to un-saturated alcohol. In contrast, Pd has more contracted d orbitals, and in this case the molecule can easily approach the surface and a flat $\eta 4$ mode is preferred [72]. As a result, Pd gives a poor selectivity in unsaturated alcohol. The calculated metal d-band width is $\mathrm{Ni}<\mathrm{Pd}<\mathrm{Ru}<\mathrm{Pt}<\mathrm{Ir}$, Os, which is in agreement with the experimentally obtained selectivities toward the un-saturated alcohol [57,73].

In the selective hydrogenation of citral, the above mentioned tendency was also shown by Vannice and Singh [53] who examined the influence of the active metal on the activity and selectivity in the liquid phase hydrogenation of citral at $300 \mathrm{~K}$ and 1 atm using silica as support. These researchers found the following trend in activity $\mathrm{Pd}>\mathrm{Pt}>\mathrm{Ir}>\mathrm{Os}>\mathrm{Ru}>\mathrm{Rh}>\mathrm{Ni}>\mathrm{Co}>>\mathrm{Fe}$ and in selectivity was found that Os showed high selectivity to unsaturated alcohols (88\%), the Ru and Co showed moderate selectivity (55\%) and $\mathrm{Rh}, \mathrm{Ni}$ and Pd were more selective to citronellal and isopulegol (0\% unsaturated alcohols). In turn, Manikandan et al. [74] analyzed $\mathrm{Pt}$ and $\mathrm{Ru}$ catalysts intercalated in a silicate (Mantmorillonite) obtaining a selectivity of $60 \%$ for Pt and $45 \%$ for Ru. Taking into account the literature review collected in Table 1 and the results obtained by Vannice and Singh, a reasonable activity trend for the most $\alpha, \beta$-unsaturated aldehydes independently of the support and the conditions employed would be the following: $\mathrm{Ni}<\mathrm{Pd} \ll<<\mathrm{Rh}<\mathrm{Ru}, \mathrm{Pt}, \mathrm{Co}<\mathrm{Ir}$, Os. 
With regard to the selectivity, the susceptibility of the Ir to the formation of un-saturated alcohols in the hydrogenation of citral as well as with other aldehydes [52] is not clear. Comparing the results (Table 1) for $\mathrm{Ir} / \mathrm{TiO}_{2}$ in the same operating conditions, some authors achieved selectivities as high as 91\%-100\% while others get a moderate selectivity of $60 \%$, whereas using other supports like $\mathrm{SiO}_{2}$, very different selectivities among $100 \%, 40 \%$ or $15 \%$ were obtained. However, it seems clear that with Ir catalyst, low conversions are achieved (5\%-10\%). Thus, despite that Os and Ir seem to be the most selective to un-saturated alcohols in the hydrogenation of citral, they are the least active. On the other hand, $\mathrm{Pt}$ and $\mathrm{Ru}$ are the most employed in the literature (they are present in $68 \%$ of the reviewed papers): Pt because it shows moderate activity and selectivity, and $\mathrm{Ru}$ because it combines an acceptable catalytic performance with the cheapest price among the best metals. Obviously, the ideal would be to achieve a high selectivity with a great conversion without losing sight of the economic factor. For this reason, the challenge is to improve the selectivity of Pt and Ru by adding a second metal or enhancing electronic effects of the support.

Table 1. Effect of the type of metal on the selectivity toward the un-saturated alcohol in the selective hydrogenation of citral.

\begin{tabular}{ccccccc}
\hline Metal & $\mathbf{S u p p o r t}$ & $\mathbf{T}^{\mathbf{a}}\left({ }^{\circ} \mathbf{C}\right)$ & $\mathbf{P}(\mathbf{B a r})$ & $\mathbf{S}(\boldsymbol{\%})$ & $\mathbf{C}(\boldsymbol{\%})$ & Ref. \\
\hline $\mathrm{Rh}$ & $\mathrm{TiO}_{2}$ & 70 & 70 & 10 & 100 & {$[75]$} \\
$\mathrm{Rh}$ & $\mathrm{TiO}_{2}$ & 70 & 70 & 11 & 94 & {$[76]$} \\
$\mathrm{Rh}$ & $\mathrm{SiO}_{2}$ & 35 & 1 & 5.2 & 100 & {$[77]$} \\
$\mathrm{Pt}$ & $\mathrm{TiO}_{2}$ & 70 & 70 & 58 & 98 & {$[75]$} \\
$\mathrm{Pt}$ & $\mathrm{TiO}_{2}$ & 90 & 100 & 68 & 95 & {$[78]$} \\
$\mathrm{Pt}$ & $\mathrm{SiO}_{2}$ & 100 & 20 & 56 & 30 & {$[79]$} \\
$\mathrm{Ir}$ & $\mathrm{TiO}_{2}$ & 90 & 6.2 & 100 & 11.2 & {$[80]$} \\
$\mathrm{Ir}$ & $\mathrm{SiO}_{2}$ & 90 & 6.2 & 47 & 5 & {$[81]$} \\
$\mathrm{Ir}$ & $\mathrm{Nb}_{2} \mathrm{O}_{5}$ & 90 & 6.2 & 82 & 15 & {$[82]$} \\
$\mathrm{Ir}$ & $\mathrm{SiO}_{2}$ & 90 & 6.2 & 44 & 3 & {$[82]$} \\
$\mathrm{Ir}$ & $\mathrm{TiO}_{2}$ & 90 & 6.2 & 91 & 10 & {$[81]$} \\
$\mathrm{Ir}$ & $\mathrm{SiO}_{2}$ & 70 & 4 & 100 & 10 & {$[83]$} \\
$\mathrm{Ir}$ & $\mathrm{TiO}_{2}$ & 70 & 4 & 100 & 10 & {$[83]$} \\
$\mathrm{Ir}$ & $\mathrm{SiO}_{2}$ & 27 & 1 & 15 & 5 & {$[44]$} \\
$\mathrm{Os}$ & $\mathrm{SiO}_{2}$ & 27 & 1 & 88 & 5 & {$[44]$} \\
$\mathrm{Co}$ & $\mathrm{TiO}_{2}$ & 90 & 70 & 50 & 80 & {$[42]$} \\
$\mathrm{Co}$ & $\mathrm{C}$ & 120 & 10 & 60 & 17 & {$[84]$} \\
$\mathrm{Au}$ & $\mathrm{TiO}_{2}$ & 80 & 40 & 16 & 6 & {$[85]$} \\
$\mathrm{Ru}$ & $\mathrm{TiO}_{2}$ & 80 & 40 & 22 & 15 & {$[85]$} \\
$\mathrm{Ru}$ & $\mathrm{TiO}_{2}$ & 126 & 50 & 42 & 76.8 & {$[86]$} \\
$\mathrm{Ru}$ & $\mathrm{Al}_{2} \mathrm{O}_{3}$ & 126 & 50 & 48 & 12.2 & {$[86]$} \\
$\mathrm{Pd}$ & $\mathrm{TiO}_{2}$ & 80 & 40 & 8 & 27 & {$[85]$} \\
$\mathrm{Pd}$ & $\mathrm{SiO}_{2}$ & 130 & 70 & 0 & 100 & {$[87]$} \\
$\mathrm{Ni}$ & $\mathrm{Al}_{2} \mathrm{O}_{3}$ & 70 & 1 & 0 & $n . d$. & {$[88]$} \\
$\mathrm{Ni}$ & $\mathrm{Cr}_{2} \mathrm{O}_{3}$ & 120 & 40 & 0 & $n . d$. & {$[89]$} \\
$\mathrm{Ni}$ & $\mathrm{Graphite}$ & 50 & 50 & 0 & 100 & {$[90]$} \\
\hline
\end{tabular}




\section{Carbon Materials as Supports}

In heterogeneous catalysis, the active phase is deposited on a support material which normally is catalytically inert. These supports are usually metal oxides or carbon with the aim of maximizing the specific surface area to achieve a greater dispersion of the active phase. However, the use of micro-mesoporous supports may not be suitable for hydrogenation reactions in liquid phase where hydrogen solubility in the solvent is small, because when very active metals are used, isomerization reactions may occur to a greater extent than the desired ones due to an immediate decrease of the hydrogen concentration on the active site [91,92]. Sometimes, we find in the literature that selectivity results in these types of reactions - including citral hydrogenation — can be affected by the above mentioned process, but the explanation is attributed to other factors.

\subsection{Activated Carbons}

The activated carbons are the supports most studied in hydrogenation of citral. These materials do not present electronic effect like the partially reducible oxides, or graphite which could enhance the selectivity towards un-saturated alcohols, but due to their high surface areas they are very interesting for the preparation of bimetallic catalysts. For these reasons, most authors who used activated carbon as support, used them for preparing bimetallic catalysts, or as reference materials.

Galvagno et al. $[43,93,94]$ studied the influence of $\mathrm{Ru}$ particle size, type or metal precursor and the reaction media, using a commercial activated carbon with a surface area between 900 and $1100 \mathrm{~m}^{2} / \mathrm{g}$ by impregnation with $\mathrm{RuCl}_{3}$ and different metal loading. Due to the high surface area of the carbon support, $\mathrm{Ru}$ could be dispersed better than using other supports such as $\mathrm{Al}_{2} \mathrm{O}_{3}$ or $\mathrm{SiO}_{2}$. Metal particle sizes among 3.7 and $10.3 \mathrm{~nm}$, with $\mathrm{Ru}$ loading among 0.5 and $10 \mathrm{wt}$ \% were obtained treating the impregnated catalysts at $300{ }^{\circ} \mathrm{C}$ in $\mathrm{H}_{2}$. They found that the specific catalytic activity per $\mathrm{Ru}$ surface atom as well as the product distribution did not depend of $\mathrm{Ru}$ particle size supported on the activated carbon. On the other hand, making a catalytic comparison among the supports activated' carbons, $\mathrm{Al}_{2} \mathrm{O}_{3}$ and $\mathrm{SiO}_{2}$ [43,94], the authors explained that due to the hydrophobic nature of the carbon support, which leads to a weaker interaction between the catalyst and the solvent (ethanol), the poisoning effect on the Ru active sites decreased, and higher amounts of unsaturated alcohols were also obtained.

On the other hand, in other works activated carbons were used to prepare bimetallic catalysts $[48,84,95-100]$ employing their high surface areas to improve the dispersion of the bimetallic clusters. Vilella et al. [99] studied the influence of the addition of different Ge and Sn loading to Pt/activated carbon catalysts. These catalysts were prepared by successive impregnation of the precursor salts $\left(\mathrm{H}_{2} \mathrm{PtCl}_{6}\right.$ and $\mathrm{SnCl}_{2}$ or $\left.\mathrm{GeCl}_{4}\right)$. They used a commercial carbon with an apparent surface area of $987 \mathrm{~m}^{2} / \mathrm{g}$ and high ash content. The activated carbon was demineralised and a fraction of this was oxidized with a $\mathrm{HNO}_{3}$ treatment. Pt-Sn catalysts worked better than Pt alone increasing both activity and selectivity towards reaching $78 \%$ of selectivity at $70 \%$ of conversion. By contrast, the addition of Ge forming the Pt-Ge clusters decreased the activity and the selectivity towards unsaturated alcohols, which was ascribed to very few oxidized Ge species being placed near Pt in order to polarize the carbonyl group of the citral molecule. This can explain the catalysts' low selectivity to unsaturated 
alcohols. Moreover, the formation of unsaturated alcohols did not improve with the addition of Ge because this would be mainly located over the support without modifying either electronically or geometrically the Pt sites. In order to enhance the numbers of Pt-Ge clusters, these catalysts were again prepared by controlled surface reactions which could ensure a contact between $\mathrm{Pt}$ and $\mathrm{Ge}$ [97] and using the oxidised activated carbon, in this case, a clear improvement of the selectivity to unsaturated alcohols was detected.

Vilella et al. [100] also studied the catalytic performance of two different activated carbon-based supports using Pt and Pt-Sn clusters: an activated carbon in powder shape against a commercial activated carbon felt. Differences in selectivity to unsaturated alcohols were found, which were ascribed to the different surface acid characteristics of the supports as well as to the presence of $\mathrm{Sn}^{\circ}$ species, being the catalysts supported on carbon powders (equilibrium $\mathrm{pH} 10$ ) more selective than that supported on carbon felts (equilibrium $\mathrm{pH} 7$ ) and obtaining a larger amount of isopulegol than the latter. $\mathrm{Sn}^{0}$ species produced blocking or dilution of de Pt particles. This effect was produced mainly on the felts based catalyst which provoked that this catalyst were less active and selective $(80 \%$ and $68 \%$ of selectivity, for activated carbon and carbon felt, respectively, at $95 \%$ of conversion)

Neri et al. [95] have also studied bimetallic Pt-Sn catalysts supported on activated carbon, prepared by co-impregnation ( $2 \mathrm{wt} . \%$ of Pt), obtaining an increase in selectivity towards unsaturated alcohols (from $40 \%-90 \%$ ) by increasing the Sn loading from 0-0.82 wt.\%.

Another bimetallic catalyst supported on carbon is Pt-Co. Bertero et al. [84] prepared Pt/C, Co/C and $\mathrm{Pt}-\mathrm{Co} / \mathrm{C}$ catalysts using a sub-bituminous carbon of high surface area $\left(1300 \mathrm{~m}^{2} / \mathrm{g}\right)$ by impregnation of acetylacetonete precursor salts. The catalysts were reduced at $150{ }^{\circ} \mathrm{C}$ and $500{ }^{\circ} \mathrm{C}$ in $\mathrm{H}_{2}$ flow. The activity and selectivity of the bimetallic catalysts were higher than the monometallic ones, suggesting the creation of new polarizated sites which would activate the $\mathrm{C}=\mathrm{O}$ bond hydrogenation. Moreover, secondary reactions such as decarbonylation and hydrogenolysis observed with the monometallic catalysts would be inhibited using the bimetallic ones.

Active carbon cloths (Figure 4) also have been employed in the selective hydrogenation of citral. Aumo et al. [101,102] studied Pt catalysts supported on carbon cloth and on woven active carbon fiber. Unsaturated alcohols selectivities of $80 \%-100 \%$ for carbon fiber catalysts were reached against a selectivity of $49 \%-62 \%$ for the activated carbon catalysts used for comparison. However, the authors mentioned that the price of these types of cloths is still a limiting factor for extended use.

Figure 4. SEM images of the (a) woven activated carbon and (b) Pt-woven activated carbon catalyst [102].

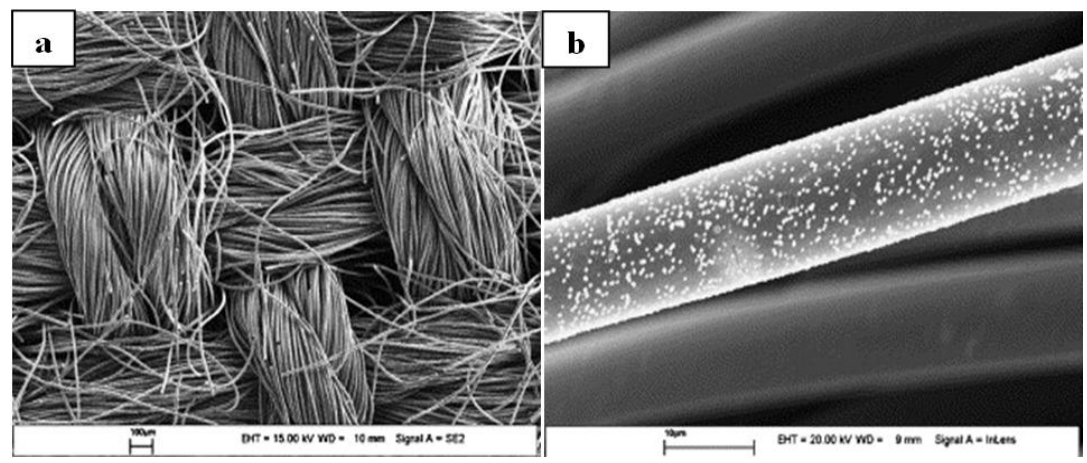




\subsection{Graphite}

In general, the literature shows that graphite-supported catalysts are more selective towards the unsaturated alcohol than other conventional supports (alumina, activated carbon, or silica). This higher selectivity would be explained on the basis of electron transfer from the graphitic support to the metal particles located at the edges of the basal planes (Figure 5). The increased charge density on the metal particles would decrease the probability of adsorption via the $\mathrm{C}=\mathrm{C}$ bond, and therefore hindering its hydrogenation [103].

Figure 5. Electron transfer from the graphitic support to the metal particles.

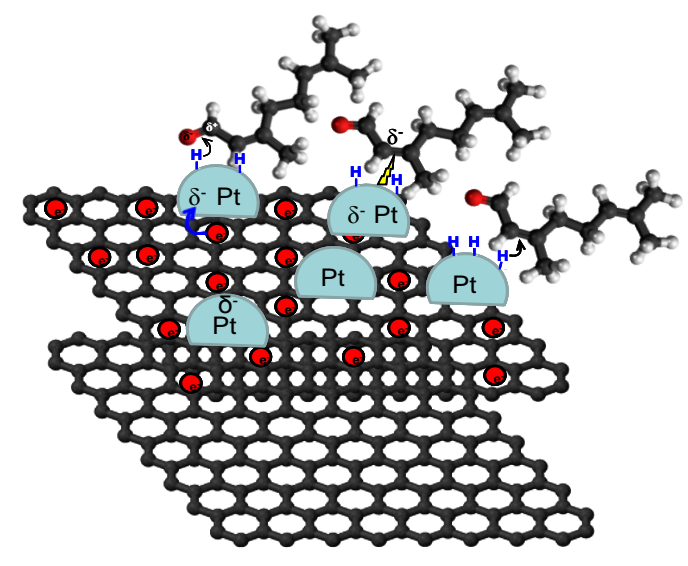

Steffan et al. [104] studied the catalytic behaviour of $\mathrm{Pt}$ catalysts supported on $\mathrm{SiO}_{2}, \mathrm{Al}_{2} \mathrm{O}_{3}$, activated carbon and graphite. The reaction was carried out at $140{ }^{\circ} \mathrm{C}, 70$ bar $\mathrm{H}_{2}, 1.5 \mathrm{~g}$ of catalyst and an initial citral concentration of $0.56 \mathrm{M}$ in n-hexane, as reaction media. They found the following trend in selectivity to unsaturated alcohols $\mathrm{Pt} / \mathrm{AC}<\mathrm{Pt} / \mathrm{Al}_{2} \mathrm{O}_{3}<\mathrm{Pt} / \mathrm{SiO}_{2}<\mathrm{Pt} / \mathrm{G}$. For the carbon based catalysts $\mathrm{Pt} / \mathrm{G}$ and $\mathrm{Pt} / \mathrm{AC}$, the use of graphite as support yielded a higher selectivity towards geraniol and nerol compared to activated carbon, in agreement with previous results for the hydrogenation of cinnamaldehyde [105]. However, this work also showed than Pt catalysts supported on graphite were much more selective to nerol and geraniol than those supported on other conventional supports such as silica or alumina.

Bachiller-Baeza et al. [106] studied $\mathrm{Ru}$ and $\mathrm{Ru}-\mathrm{Fe}$ catalysts supported on a high-surface-area graphite $\left(S_{\text {BET }} 295 \mathrm{~m}^{2} / \mathrm{g}\right)$ and activated carbon $\left(\mathrm{S}_{\mathrm{BET}} 964 \mathrm{~m}^{2} / \mathrm{g}\right)$. The activated carbon was demineralised by acid treatments, and the graphite was treated in $\mathrm{He}$ at $900{ }^{\circ} \mathrm{C}$ in order to remove the surface oxygen groups. Monometallic catalysts were prepared by incipient wetness of the supports with an aqueous solution of $\mathrm{RuNO}\left(\mathrm{NO}_{3}\right)_{3}$, and bimetallic catalysts were prepared by a co-impregnation method with aqueous solution of $\mathrm{RuNO}\left(\mathrm{NO}_{3}\right)_{3}$ and $\mathrm{Fe}\left(\mathrm{NO}_{3}\right)_{3} \cdot 9 \mathrm{H}_{2} \mathrm{O}$. The catalysts were reduced in $\mathrm{H}_{2}$ flow at $400{ }^{\circ} \mathrm{C}$ for $2 \mathrm{~h}$. The liquid-phase hydrogenation of citral was carried out in isopropanol at atmospheric pressure under $\mathrm{H}_{2}$ at $60{ }^{\circ} \mathrm{C}, 850 \mathrm{rpm}$ of agitation. A citral/Ru molar ratio of 30 was used. Contrary to what was expected the initial activities and the selectivity to unsaturated alcohols $(\sim 38 \%)$ for both monometallic Ru catalysts were similar. Authors ascribed this behaviour to the absence of oxygen groups at the surface of the graphite during the impregnation which would restrain the metal-support interaction. Oxygen groups were not present on the support before impregnation, but they were introduced into the carbon materials during the catalyst preparation procedure due to the 
very high oxidizing character of the ruthenium precursor $\left(\operatorname{RuNO}\left(\mathrm{NO}_{3}\right)_{3}\right)$. The presence of these oxygen functional groups at the surface of the graphite also impeded the electron donor effect of the macro-ligand graphite. On the other hand, using Fe as promoter, the selectivity was enhanced due to the bimetallic effect. However, bimetallic catalysts supported on graphite achieved higher selectivity to unsaturated alcohols than those on activated carbon probably due to the lower oxygen content and the maximum electronic transfer from support to the metals. This work clearly shows the importance of the surface chemistry of carbon materials in the selective hydrogenation of citral.

Asedegbega-Nieto et al. [90] studied the catalytic behaviour of $\mathrm{Ru}-\mathrm{Cu}$ and $\mathrm{Ni}-\mathrm{Cu}$ bimetallic catalysts supported on a high surface area graphite. Bimetallic catalysts with different $\mathrm{Cu}$ loadings were prepared by a co-impregnation method employing ethanolic solutions of ruthenium acetyl acetonate and copper acetate for the $\mathrm{Ru}-\mathrm{Cu}$ system, and nickel nitrate and copper nitrate for the $\mathrm{Ni}-\mathrm{Cu}$ system. The graphite was treated under inert atmosphere at $900{ }^{\circ} \mathrm{C}$ in order to remove oxygen groups before its impregnation, and the catalysts were treated in hydrogen flow at $350{ }^{\circ} \mathrm{C}$, for the $\mathrm{Ru}-\mathrm{Cu}$ system, and $350{ }^{\circ} \mathrm{C}$ for the $\mathrm{Ni}-\mathrm{Cu}$ system, both for $2 \mathrm{~h}$. The reaction were carried out at 50 bar of pressure, $50{ }^{\circ} \mathrm{C}$, initial citral concentration of $0.03 \mathrm{M}$ in isopropanol under $500 \mathrm{rpm}$ of stirring. Regarding the $\mathrm{Ru}-\mathrm{Cu}$ system, the monometallic catalyst (only $\mathrm{Ru}$ ) produced citronellal and unsaturated alcohols. The addition of $\mathrm{Cu}$ did not modify the activity, but the selectivity to unsaturated alcohols decreased probably due to a poor $\mathrm{Ru}-\mathrm{Cu}$ interaction where the $\mathrm{Cu}$ phase would be mainly covering the $\mathrm{Ru}$ particles. Regarding the Ni-Cu system, the saturated aldehydes were the main product obtained, and when $\mathrm{Cu}$ was added, changes in the selectivity were not observed. Therefore, $\mathrm{Cu}$ did not enhance selectivity to unsaturated alcohols in any case.

Court et al. [107] prepared $\mathrm{Ni}-\mathrm{M}(\mathrm{M}=\mathrm{Al}, \mathrm{Cr}, \mathrm{Cu}, \mathrm{Co}, \mathrm{Mo})$ bimetallic catalyst supported on graphite by incipient wetness using an aqueous solution of the appropriated composition of the two metal salts, and later reduction with naphthalene sodium. Hydrogenations were carried out at $80{ }^{\circ} \mathrm{C}$ under constant hydrogen pressure (1.01 MPa) using a citral concentration in 2-propanol of $0.195 \mathrm{M}$. It was expected that $\mathrm{Ni}-\mathrm{Cr}$ catalysts were more selective to citronella1 whereas $\mathrm{Ni}-\mathrm{Mo}$ catalysts were more selective to citronellol. However, in none of the cases, the bimetallic catalysts modified the selectivity of Ni to unsaturated alcohols.

Cerro-Alarcón et al. [108] studied the behaviour of Ni catalysts supported on a high surface area graphite $\left(200 \mathrm{~m}^{2} / \mathrm{g}\right)$ and $3 \mathrm{wt} . \%$ oxygen surface content. Two different metal salts were used, namely, $\mathrm{Ni}\left(\mathrm{NO}_{3}\right)_{2} \cdot 6 \mathrm{H}_{2} \mathrm{O}$ and $\mathrm{Ni}\left(\mathrm{CH}_{3} \mathrm{COO}\right)_{2} \cdot 4 \mathrm{H}_{2} \mathrm{O}$, and with different pre-treatment: reduction in $\mathrm{H}_{2}$ at $400{ }^{\circ} \mathrm{C}$ for $2 \mathrm{~h}$, and hydrazine based treatments; reduction of the impregnated support directly with hydrazine, or reduction-deposition in situ of $\mathrm{Ni}$ precursor with hydrazine. The hydrogenation of citral was performed operating at $50{ }^{\circ} \mathrm{C}, \mathrm{a} \mathrm{H}_{2}$ pressure of $5 \mathrm{MPa}$, under $500 \mathrm{rpm}$ of stirring, and using around $0.4-0.5 \mathrm{~g}$ catalyst and $0.4-0.5 \mathrm{~mL}$ of citral in $100 \mathrm{~mL}$ of 2-propanol. The catalytic results indicated that the determining factor in the activity data was the reduction method employed independently of the $\mathrm{Ni}$ precursor. While the treatment of reduction in hydrogen flow $\mathrm{Ni}^{\circ}$ was obtained, the reduction with hydrazine provided low proportions of $\mathrm{Ni}^{\circ}$ sites and mainly oxidised $\mathrm{Ni}^{2+}$ and/or $\mathrm{Ni}^{3+}$ species. These oxidised $\mathrm{Ni}$ species can activate the unsaturated aldehyde hydrogenation via the $\mathrm{C}=\mathrm{O}$ bond. In fact, when only $\mathrm{Ni}^{\circ}$ was present the hydrogenation activity was the highest; several orders of magnitude higher than those observed for catalysts prepared by reduction with hydrazine, however, these catalysts were not selective to the unsaturated alcohol formation. On the contrary, catalysts 
pre-treated with hydrazine were much more selective to unsaturated alcohols than the hydrogen pre-treated ones, but with very poor activities.

Zhao et al. [109] prepared catalysts for the selective hydrogenation of citral towards citronellal, instead to the unsaturated alcohols, using Pd catalysts supported on a graphite oxide (GO) pre-treated with 1,1,3,3-tetramethylguanidine (TMG). It is known that the use of palladium-supported catalysts in citral hydrogenations together with basic promoters, such as $\mathrm{NaOH}$ or $\mathrm{NaCO}_{3}$, leads to higher selectivity toward citronellal $[110,111]$. In this case, the above mentioned procedure was the basis to modify the GO surface for immobilizing $\mathrm{Pd}$ nanoparticles and using $\mathrm{Pd}\left(\mathrm{CH}_{3} \mathrm{COO}\right)_{2}$ in ethanol solution. In a last step, the catalyst was reduced in a $\mathrm{NaBH}_{4}$ aqueous solution, obtaining the GO supported $\mathrm{Pd}$ nanocatalysts. This type of catalyst had small Pd particle sizes, in a narrow size distribution, which produced a selectivity to citronellal of $89.6 \%$ with a high activity.

\subsection{Carbon Nanotubes}

Recently [32], carbon nanotube (CNT) structures have been found to produce remarkable catalytic effects when they are used as a support for selective hydrogenation reactions due to their unique properties such as excellent electrical and thermal conductivity, uniform pore size distribution, development of meso and macropore bodies [112], and high length-to-diameter aspect ratio, the latter providing them a high external surface area [113]. These special properties could influence the metallic particle size distribution, dispersion, metal oxidation state, but also can reduce problems as mass transfer rates obtaining high catalytic performances in comparison with other conventional supports [114]. Besides, due to their three-dimensional nanoscale structure of rolled up graphene layers, a transfer of electronic density from the support to the deposited metallic particles [115,116] could take place affecting the properties of the metallic phase and their catalytic behaviour [117]. For these reasons, they have been recently used as supports in the hydrogenation selective of citral, because they can improve the selectivity to the unsaturated alcohol due to a transfer of the p-electrons from the graphene layer to the metal particles. Moreover, the curvature of the CNT channel could also induce an extra modification on the molecular adsorption on the metallic phase, which also would modify the catalytic activity and/or selectivity of the hydrogenation reaction. However, during the CNT synthesis other carbon forms and amorphous carbon are formed as well. Therefore, it is necessary to have a good knowledge of the purity of CNT when using them for catalytic applications.

Asedegbega-Nieto et al. [118], studied the catalytic behaviour of four different carbon materials, including two types of carbon nanotubes with very similar sizes, as supports of Pt catalysts: commercial carbon nanotubes obtained by arc discharge (CNT1) with a 30-40 wt.\% of nanotube content, carbon nanotubes obtained by CVD (CNT2), carbon black and a high surface area graphite, pretreated at $900{ }^{\circ} \mathrm{C}$ in $\mathrm{He}$ flow in order to remove surface groups. The Pt catalysts were prepared by impregnation of the supports with hexachloroplatinic acid obtaining the smallest particle sizes on graphite and carbon black probably due to their highest surface area in comparison with CNTs. Figure 6 shows some pictures of Pt supported on carbon nanotubes. Citral hydrogenation reactions were carried out at $50{ }^{\circ} \mathrm{C}$ and $\mathrm{H}_{2}$ pressure of 50 bar, with $500 \mathrm{rpm}$ of stirring, employing isopropanol as solvent. Regarding the catalytic results, Pt supported on carbon, graphite and CNT1 showed similar selectivity to unsaturated alcohols, around $30 \%$, but using CNT2 which had much fewer carbon impurities, a 
selectivity of $62 \%$ was achieved. The presence of graphitized carbon in CNT1 conferred to this catalyst a behaviour similar to the graphite-supported one, probably because the Pt particles were localized mainly on the carbon impurities, which have a flat-like morphology and not the round-shaped structure of CNTs; consequently, the carbon impurities did not produce the effect of electronic transfer of the CNTs. In this line, Qin et al. [119] also obtained higher selectivity using carbon nanotubes produced by CVD than using activated carbon as supports of Pt catalysts: $59 \%$ vs. $26 \%$, respectively.

Figure 6. Pt catalysts supported on carbon nanotubes [118].
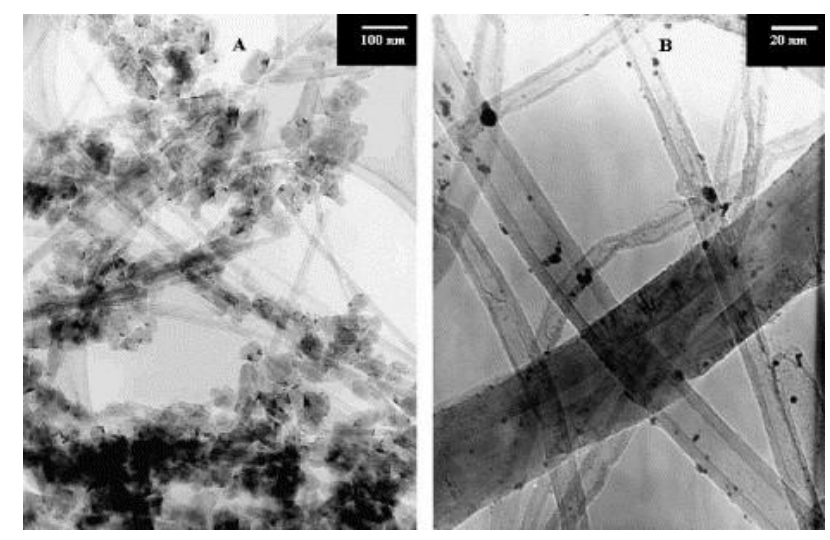

Functionalized carbon nanotubes have also been studied as catalyst supports similar to graphite. So, Qin et al. $[119,120]$ modified carbon nanotubes by functionalization with polyacrylic acid (PAA). In this work Pt was introduced into pure and PAA grafting multi-walled carbon nanotubes (MWNTs) by electroless metal deposition method as used as catalysts for hydrogenation of citral. These catalysts exhibited higher activity when compared with Pt impregnated activated carbon catalyst, similar to previous discussed results [118]. However, a decrease in the selectivity to unsaturated alcohols from $59 \%$ for MWNTs without functionalization, to $7 \%$ for PAA grafted MWNTs, was observed. This result is related to the large amount of carboxylic groups that PAA treatment fixed on the outside of the MWNTs, which decreased the electronic effect of the support. Moreover, PAA prevented the formation of $\mathrm{Pt}\{111\}$ affecting the various product distributions obtained. The PAA treatment in the nanotube leads to better dispersion of Pt nanoparticles and, therefore, better activities, but worse selectivity towards unsaturated alcohols.

Zgolicz et al. [121] also functionalized carbon nanotubes by thermal and oxidative treatments. Pt and Pt-Fe catalysts supported by multi-wall carbon nanotubes were developed to study the influence of the support surface composition on the catalytic performance for the unsaturated alcohols. The citral hydrogenation was performed at $70{ }^{\circ} \mathrm{C}$ and atmospheric pressure in a discontinuous reactor using 0.3 $\mathrm{mL}$ of citral, $0.300 \mathrm{~g}$ of catalyst in $30 \mathrm{~mL}$ of 2-propanol. Low numbers of oxygen groups on the support surface produced an optimized Pt size. The Pt loading of the catalysts was 5 wt.\% which together with the presence of $\mathrm{Fe}$, yields a very high selectivity $(96 \%)$ to unsaturated alcohols.

Bimetallic catalysts have also been prepared using CNT as supports. Ananthan et al. [122] prepared $\mathrm{Pt}, \mathrm{Ru}$ and Pt-Ru catalysts over carbon nanotubes to study the effect of these bimetallic particles. They also studied the effect on the catalysts of the carbon nanotube surface chemistry by a previous functionalization of the support with nitric acid followed by two different heat treatments $\left(375^{\circ} \mathrm{C}\right.$ and 
$675^{\circ} \mathrm{C}$ in $\mathrm{N}_{2}$ flow), in order to partially remove the oxygen-containing groups from the CNT surface. The catalytic results showed that as expected the removal of oxygen-containing groups increased both activity and selectivity. In fact, the selectivity to the unsaturated alcohols reached $95 \%$ by using bimetallic catalysts, due to a close contact between Pt and $\mathrm{Ru}$ nanoparticles where a charge transfer could be developed from $\mathrm{Ru}$ to Pt atoms. Recently [123], these authors have developed Pt-Au bimetallic catalysts supported on CNT confirming the above mentioned effect of the oxygen groups on $\mathrm{CNT}$, however the Pt-Ru system was more selective to unsaturated alcohols than the Pt-Au; $95 \%$ vs. $70 \%$, respectively.

\subsection{Composite Materials}

By attempting to combine the carbon materials and partially reducible oxide properties, new composite materials have been developed as supports for the selective hydrogenation of citral. In this line, the influence of the supports carbon- $\mathrm{TiO}_{2}$ and carbon- $\mathrm{CeO}_{2}$ on the deposited metal phase have been mainly studied [96,124-127].

Partilly $\mathrm{Pt}$ catalyst supported by reducible oxides have shown very good selectivity to $\mathrm{C}=\mathrm{O}$ bond hydrogenation as it was described [78,128]. Figure 7 shows a scheme for the preferred orientation of citral when it is hydrogenated on $\mathrm{TiO}_{2}$ [75], pretreated at high temperatures.

Figure 7. Citral being hydrogenated on $\mathrm{Pt}$ supported on $\mathrm{TiO}_{2} \cdot \bigcirc \mathrm{Ti}^{3+}$ or $\mathrm{Ti}^{4+}$ species and $\square$ oxygen vacancies and $\Leftrightarrow \mathrm{C}=\mathrm{O}$ bond $[75,129]$.

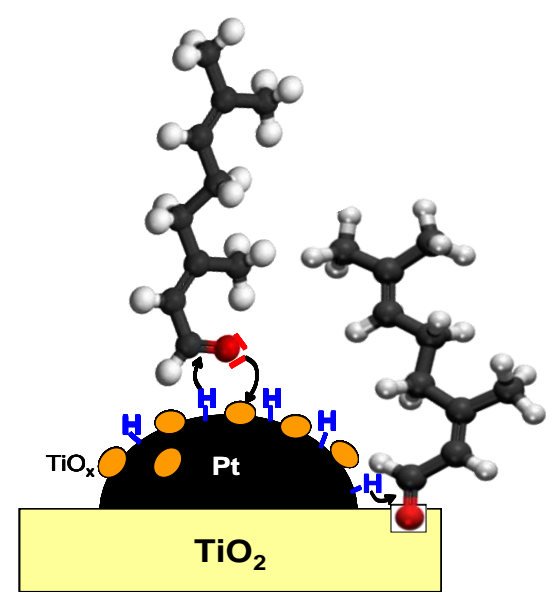

Zhu et al. prepared carbon nanofibers (CNFs)- $\mathrm{TiO}_{2}$ composites [125-127] as supports for $\mathrm{Pd}$ catalysts. In this way, $\mathrm{TiO}_{2}$ was impregnated with aqueous solutions of $\mathrm{Ni}\left(\mathrm{NO}_{3}\right)_{2} \cdot 6 \mathrm{H}_{2} \mathrm{O}$ or mixture of $\mathrm{Ni}\left(\mathrm{NO}_{3}\right)_{2} \cdot 6 \mathrm{H}_{2} \mathrm{O}$ and $\mathrm{Cu}\left(\mathrm{NO}_{3}\right)_{2} \cdot 3 \mathrm{H}_{2} \mathrm{O}$, and then a reduction treatment at $600{ }^{\circ} \mathrm{C}$ in $\mathrm{N}_{2} / \mathrm{H}_{2}(80: 20)$ was carried out. CNFs were grown by methane decomposition at $873 \mathrm{~K}$ for $5 \mathrm{~h}$, and finally, $\mathrm{Ni}$ and $\mathrm{Cu}$ particles were removed by means of a treatment with $\mathrm{HNO}_{3}$ at $120{ }^{\circ} \mathrm{C}$. A $\mathrm{TiO}_{2}$ coated cordierite monolith was also prepared by a sol-gel method [126] which also was used for CNFs growing. The $\mathrm{CNF}^{-\mathrm{TiO}_{2}}$ support contained $38 \%$ of carbon phase, which was composed by CNFs, 95\%, and amorphous carbon, 5\%. Pd catalyst was prepared by impregnation with an aqueous solution of $\mathrm{PdCl}_{2}$ and then it was tested in the citral hydrogenation with the aim of obtaining citronellal as the main product. A commercial $\mathrm{Pd} /$ activated carbon catalyst $(\mathrm{Pd} / \mathrm{AC})$ was also tested for comparison. 
$\mathrm{Pd} / \mathrm{CNF}-\mathrm{TiO}_{2}$ catalyst had a very low surface area- $58.1 \mathrm{~m}^{2} / \mathrm{g}$ versus $810 \mathrm{~m}^{2} / \mathrm{g}$ - of Pd/activated carbon. Moreover, the porosity was also very different being that $\mathrm{Pd} / \mathrm{CNF}-\mathrm{TiO}_{2}$ is mainly mesoporous with an average pore diameter of $9.7 \mathrm{~nm}$ while $\mathrm{Pd} / \mathrm{AC}$ was microporous with an average pore diameter of $2.1 \mathrm{~nm}$. Regarding the activity and selectivity of these supports, Pd/AC was more active than $\mathrm{Pd} / \mathrm{CNF}-\mathrm{TiO}_{2}(90 \%$ conversion after $4 \mathrm{~h}$ and $32 \mathrm{~h}$, respectively) which could be explained by the higher Pd dispersion and narrow Pd particle size distribution in Pd/AC due to its larger surface area; conversely, a poorly dispersed catalyst with larger $\mathrm{Pd}$ particles was obtained over $\mathrm{Pd} / \mathrm{CNF}-\mathrm{TiO}_{2}$ due to its smaller surface area which would lead to lower catalytic activity than for Pd/AC. In regards to selectivity to citronellal, considering that palladium catalysts are very active in the hydrogenation of the $\mathrm{C}=\mathrm{C}$ bonds, the selectivity towards citronellal was expected to be very high in both cases, however the selectivity towards citronellal achieved with $\mathrm{Pd} / \mathrm{CNF}-\mathrm{TiO}_{2}$ was significantly higher than $\mathrm{Pd} / \mathrm{AC}$, and particularly at high conversion ( $88 \%$ versus $35 \%$ selectivity, respectively, at $90 \%$ conversion). This result suggested that the porosity of the supports could play an important role, as explained by the following: on the catalyst external surface citral would be firstly hydrogenated to citronellal and then citronellal can be easily desorbed from Pd crystals to the solution. Inside the porosity, the product distribution should be different. If the reaction took place in the macro- and meso-pore network of the catalyst, the main products would be citronellal as they occur on the external surface because these pore sizes are wide enough to not influence product diffusions, while if the reaction took place inside the micropores, citral would also be hydrogenated to citronellal but it would be confined inside the micropores and, therefore, it would be completely hydrogenated to 3,7-dimethyloctanol. According to this explanation, at low conversions the selectivity to citronellal was similar in both catalysts due to only the external surface being involved in the reaction, however, at higher conversions, the selectivity to citonellal using $\mathrm{Pd} / \mathrm{AC}$ decreased, increasing the formation of 3,7-dimethyloctanol in the microporosity of the active carbon.

Regarding the $\mathrm{TiO}_{2}$ coated cordierite monolith [126], it was used to grow CNFs in order to be employed as structured supports of Pd catalyst as well. The obtained results showed a very good selectivity to citronellal which was also explained in terms of decreasing internal diffusion limitation.

On the other hand, Serrano-Ruiz et al. [96] dispersed ceria on a carbon Norit in order to enhance the amount and surface area of partially reducible $\mathrm{CeO}_{2}$ sites which acts to improve the selectivity towards unsaturated alcohols. The composite material was prepared by impregnation of carbon (previously outgassed) with an acetonic solution of $\mathrm{Ce}\left(\mathrm{NO}_{3}\right)_{3} \cdot 6 \mathrm{H}_{2} \mathrm{O}$ obtaining a $\mathrm{CeO}_{2}$ loading of $20 \mathrm{wt}$.\%. On this support, $\mathrm{Pt}$ and $\mathrm{Pt}-\mathrm{Sn}$ catalysts were deposited, and then, they were pre-treated at both $200{ }^{\circ} \mathrm{C}$, and $500{ }^{\circ} \mathrm{C}$, in order to evaluate the strong metal-support interactions effect. Bimetallic catalyst achieved higher selectivity to unsaturated alcohols than monometallic ones, increasing the selectivity parallel to the amount of Sn; however, regarding the conversion, the trends were the opposite: conversion decreased when the Sn loading increased which was ascribed to some Pt particles being able to be covered by $\mathrm{Sn}$ species. On the other hand, reduction treatment at $500{ }^{\circ} \mathrm{C}$ increased the selectivity to geraniol and nerol by $50 \%$ in both monometallic and bimetallic catalysts, explained by the presence of new $\mathrm{Pt}-\mathrm{SnO}_{\mathrm{x}}$ and/or $\mathrm{Pt}-\mathrm{CeO}_{\mathrm{x}}$ active sites. It is noteworthy that although bimetallic cluster and partially reducible oxide were used, and being well known that both favour the $\mathrm{C}=\mathrm{O}$ bond hydrogenation, a selectivity to unsaturated alcohol was achieved that was not too high $(35 \%)$. 
Bachiller-Baeza et al. [124] also prepared composite materials, as supports of Ru catalysts, using $\mathrm{Ce}$ or $\mathrm{Mg}$ as promoter phases in combination with activated carbon (AC) or $\mathrm{Al}_{2} \mathrm{O}_{3}$. Composites were prepared by different impregnations procedures, where $\mathrm{RuNO}\left(\mathrm{NO}_{3}\right)_{3}$ pre-impregnated supports, $\mathrm{Ru} / \mathrm{AC}$ or $\mathrm{Ru} / \mathrm{Al}_{2} \mathrm{O}_{3}$, were again impregnated with aqueous solutions of $\mathrm{Ce}\left(\mathrm{NO}_{3}\right)_{3}$ or $\mathrm{Mg}\left(\mathrm{NO}_{3}\right)_{2}$. All the composite catalysts and $\mathrm{Ru}$ free supports were tested in the selective hydrogenation of citral and crotonaldehyde. Addition of $\mathrm{MgO}$ or $\mathrm{CeO}_{2}$ decreased the hydrogenation activity. However, while $\mathrm{MgO}$ did not influence the selectivity, $\mathrm{CeO}_{2}$ increased the selectivity to unsaturated alcohols, especially on carbon supported catalysts. Finally, the authors suggested that defects on the surface of the promoter were highly selective sites for unsaturated aldehydes hydrogenation due to their influence on the $\mathrm{C}=\mathrm{O}$ bond activation.

\section{Conclusions}

Three types of carbon materials have been mainly used as catalyst supports in the selective hydrogenation of citral: activated carbons, graphite, and carbon nanotubes. In most cases, Pt was the metal supported, followed by $\mathrm{Ru}$, and only a few works have been found focusing on the use of carbon composite materials in this reaction. It is noteworthy that no work has been found where carbon aerogels or xerogels were used as support, in spite of the extensive uses these materials have for very different catalyzed heterogeneous reactions. Carbon materials have shown very good performance as catalyst support for citral hydrogenation; both characteristic porosity and chemical surface can be used to modify selectivity in different ways. Moreover, very high selectivity to the unsaturated alcohols nerol and geraniol has also been reported in some cases. It should be mentioned that the amount of work discovered for citral hydrogenation is smaller than that of other $\alpha, \beta$-unsaturated aldehydes. Thus, we consider that it is still possible to improve the catalyst development for this reaction, which is a challenge that can be addressed with new carbon materials, such as carbon gels, carbon nanotubes or carbon fibers, or new carbon material-oxide composites, though optimizing in all cases the metal particle sizes and their distribution throughout the porosity of the supports.

\section{Acknowledgments}

This work is supported by the MICINN-FEDER, project CTM2010-18889.

\section{Conflicts of Interest}

The authors declare no conflict of interest.

\section{References}

1. Baser, K.H.C.; Kürkçüoglu, M.; Demirci, B. Ninde Oil (Aeollanthus myrianthus Taylor) Revisited: Analysis of a Historical Oil. J. Essent. Oil Res. 2005, 17, 137-138.

2. Baydar, H.; Baydar, N.G. The effects of harvest date, fermentation duration and Tween 20 treatment on essential oil content and composition of industrial oil rose (Rosa damascena Mill.). Ind. Crop. Prod. 2005, 21, 251-255. 
3. Dubey, V.S.; Luthra, R. Biotransformation of geranyl acetate to geraniol during palmarosa (Cymbopogon martinii, Roxb. wats. var. motia) inflorescence development. Phytochemistry 2001, 57, 675-680.

4. Simon, D.Z.; Beliveau, J.; Aube, C. Extraction by hydrodiffusion of the essential oil of Monarda fistulosa grown in the province of Quebec: Assay of geraniol in the hydrodiffused oil. Int. J. Crude Drug Res. 1986, 24, 120-122.

5. Rajeswara Rao, B.R.; Bhattacharya, A.K.; Mallavarapu, G.R.; Ramesh, S. Yellowing and crinkling disease and its impact on the yield and composition of the essential oil of citronella (Cymbopogon winterianus Jowitt.). Flavour Frag. J. 2004, 19, 344-350.

6. Bedoukian, P.Z. Geraniol and Nerol. Perfumery and Flavoring Synthetics; Allured Publishing Corporation: Wheaton, State, USA, 1986.

7. Clark, G.S. Geraniol. Perfum. Flavorist 1998, 23, 19-25.

8. Rastogi, S.C.; Johansen, J.D.; Frosch, P.; Menne, T.; Bruze, M.; Lepoittevin, J.P.; Dreier, B.; Andersen, K.E.; White, I.R. Deodorants on the European market: Quantitative chemical analysis of 21 fragrances. Contact Dermatitis 1998, 38, 29-35.

9. Rastogi, S.C.; Heydorn, S.; Johansen, J.D.; Basketter, D.A. Fragrance chemicals in domestic and occupational products. Contact Dermatitis 2001, 45, 221-225.

10. Rastogi, S.C.; Johansen, J.D.; Menné, T. Natural ingredients based cosmetics. Content of selected fragrance sensitizers. Contact Dermatitis 1996, 34, 423-426.

11. Chen, W.; Viljoen, A.M. Geraniol: A review of a commercially important fragrance material. S. Afr. J. Bot. 2010, 76, 643-651.

12. Sato, K.; Krist, S.; Buchbauer, G. Antimicrobial effect of vapours of geraniol, (R)-(-)-linalool, terpineol, $\gamma$-terpinene and 1,8-cineole on airborne microbes using an airwasher. Flavour Frag. J. 2007, 22, 435-437.

13. Bugband. Available online: http://www.bugband.net (accessed on 4 August 2013).

14. Fulltec. Available online: http://www.fulltec.org (accessed on 4 August 2013).

15. Papachristos, D.P.; Karamanoli, K.I.; Stamopoulos, D.C.; Menkissoglu-Spiroudi, U. The relationship between the chemical composition of three essential oils and their insecticidal activity against Acanthoscelides obtectus (Say). Pest Manag. Sci. 2004, 60, 514-520.

16. Ji, P.; Si, M.S.; Podnos, Y.; Imagawa, D.K. Monoterpene geraniol prevents acute allograft rejection. Transplant. Proc. 2002, 34, 1418-1419.

17. Hierro, I.; Valero, A.; Pérez, P.; González, P.; Cabo, M.M.; Montilla, M.P.; Navarro, M.C. Action of different monoterpenic compounds against Anisakis simplex s.l. L3 larvae. Phytomedicine 2004, 11, 77-82.

18. Navarro, M.C.; Noguera, M.A.; Romero, M.C.; Montilla, M.P.; González de Selgas, J.M.; Valero, A. Anisakis simplex s.l.: Larvicidal activity of various monoterpenic derivatives of natural origin against L3 larvae in vitro and in vivo. Exp. Parasitol. 2008, 120, 295-299.

19. Edris, A.E. Pharmaceutical and therapeutic potentials of essential oils and their individual volatile constituents: A review. Phytother. Res. 2007, 21, 308-323.

20. Tiwari, M.; Kakkar, P. Plant derived antioxidants-Geraniol and camphene protect rat alveolar macrophages against t-BHP induced oxidative stress. Toxicol Vitro 2009, 23, 295-301. 
21. Shoji, Y.; Ishige, H.; Tamura, N.; Iwatani, W.; Norimatsu, M.; Shimada, J.; Mizushima, Y. Enhancement of anti-herpetic activity of antisense phosphorothioate oligonucleotides 5 ' end modified with geraniol. J. Drug Targeting 1998, 5, 261-273.

22. Ahmad, S.T.; Arjumand, W.; Seth, A.; Nafees, S.; Rashid, S.; Ali, N.; Sultana, S. Preclinical renal cancer chemopreventive efficacy of geraniol by modulation of multiple molecular pathways. Toxicology 2011, 290, 69-81.

23. Kim, S.H.; Bae, H.C.; Park, E.J.; Lee, C.R.; Kim, B.J.; Lee, S.; Park, H.H.; Kim, S.J.; So, I.; Kim, T.W.; Jeon, J.H. Geraniol inhibits prostate cancer growth by targeting cell cycle and apoptosis pathways. Biochem. Biophys. Res. Commun. 2011, 407, 129-134.

24. Madankumar, A.; Jayakumar, S.; Asokkumar, S.; Raghunandhakumar, S.; Naveenkumar, C.; Devaki, T. Chemopreventive potential of geraniol on 4-Nitroquinoline-1 oxide induced oral carcinogenesis in rats. Int. J. Res. Pharm. Sci. 2011, 2, 531-536.

25. Polo, M.P.; de Bravo, M.G. Effect of geraniol on fatty-acid and mevalonate metabolism in the human hepatoma cell line Hep G2. Biochem. Cell B 2006, 84, 102-111.

26. Wiseman, D.A.; Werner, S.R.; Crowell, P.L. Cell cycle arrest by the isoprenoids perillyl alcohol, geraniol, and farnesol is mediated by p21 Cip1 and p27 Kip1 in human pancreatic adenocarcinoma cells. J. Pharm. Exp. Ther. 2007, 320, 1163-1170.

27. Groling, J. Ullmann's Encyclopedia of Industrial Chemistry; Willey-VCH: Weinheim, Germany, 2003.

28. Eisenacher, M.; Beschnitt, S.; Hölderich, W. Novel route to a fruitful mixture of terpene fragrances in particular phellandrene starting from natural feedstock geraniol using weak acidic boron based catalyst. Catal. Commun. 2012, 26, 214-217.

29. Somogyi, L.P.;Kishi, A. Aroma Chemicals and the Flavour and Fragrance Industry; Chemical Economics Handbook (CEH) Product Review; Technical Report for SRI International: Menlo Park, CA, USA, August 2001.

30. Weiss, R. Hydrochlorination of Myrcene. U.S. patent 28823223, 14 April 1959.

31. Surburg, H.; Panten, J. Common Fragrance and Flavor Materials: Preparation, Properties and Uses; WILEY-VCH: Weinheim, Germany, 2006.

32. Serp, P.; Figueiredo, J.L. Carbon Materials for Catalysis; John Wiley \& Sons: Hoboken, NJ, USA, 2009.

33. Pérez-Cadenas, A.F.; Ros, C.H.; Morales-Torres, S.; Pérez-Cadenas, M.; Kooyman, P.J.; Moreno-Castilla, C.; Kapteijn, F. Metal-doped carbon xerogels for the electro-catalytic conversion of $\mathrm{CO}_{2}$ to hydrocarbons. Carbon 2013, 56, 324-331.

34. Moreno-Castilla, C.; Maldonado-Hódar, F.J. Carbon aerogels for catalysis applications: An overview. Carbon 2005, 43, 455-465.

35. Morales-Torres, S.; Maldonado-Hódar, F.J.; Pérez-Cadenas, A.F.; Carrasco-Marín, F. Design of low-temperature Pt-carbon combustion catalysts for VOC's treatments. J. Hazard. Mater. 2010 , $183,814-822$.

36. Maldonado-Hódar, F.J.; Moreno-Castilla, C.; Pérez-Cadenas, A.F. Catalytic combustion of toluene on platinum-containing monolithic carbon aerogels. Applied Catalysis B: Environmental 2004, 54, 217-224. 
37. Duarte, F.; Maldonado-Hódar, F.J.; Pérez-Cadenas, A.F.; Madeira, L.M. Fenton-like degradation of azo-dye Orange II catalyzed by transition metals on carbon aerogels. Appl. Catal. B 2009, 85, 139-147.

38. Samant, P.V.; Pereira, M.F.R.; Figueiredo, J.L. Mesoporous carbon supported Pt and Pt-Sn catalysts for hydrogenation of cinnamaldehyde. Catal. Today 2005, 102-103, 183-188.

39. Mahata, N.; Gonçalves, F.; Pereira, M.F.; Figueiredo, J.L. Selective hydrogenation of cinnamaldehyde to cinnamyl alcohol over mesoporous carbon supported $\mathrm{Fe}$ and $\mathrm{Zn}$ promoted $\mathrm{Pt}$ catalyst. Appl. Catal. A 2008, 339, 159-168.

40. Machado, B.F.; Morales-Torres, S.; Pérez-Cadenas, A.F.; Maldonado-Hódar, F.J.; Carrasco-Marín, F.; Silva, A.M.T.; Figueiredo, J.L.; Faria, J.L. Preparation of carbon aerogel supported platinum catalysts for the selective hydrogenation of cinnamaldehyde. Appl. Catal. A 2012, 425-426, 161-169.

41. Giroir-Fendler, A.; Richard, D.; Gallezot, P. Heterogeneus Catalysis and Fine Chemicals. Studies in Surface Science and Catalysis.; Elsevier: Amsterdam, Netherlands, 1988.

42. Kouachi, K.; Lafaye, G.; Especel, C.; Cherifi, O.; Marecot, P. Effects of support and metal loading on the characteristics of Co based catalysts for selective hydrogenation of citral. J. Mol. Catal. A 2008, 280, 52-60.

43. Neri, G.; Mercadante, L.; Donato, A.; Visco, A.M.; Galvagno, S. Influence of Ru precursor, support and solvent in the hydrogenation of citral over ruthenium catalysts. Catal. Lett. 1994, 29, 379-386.

44. Singh, U.K.; Vannice, M.A. Liquid-phase citral hydrogenation over $\mathrm{SiO}_{2}$-supported group VIII metals. J. Catal. 2001, 199, 73-84.

45. Coq, B.; Kumbhar, P.S.; Moreau, C.; Moreau, P.; Warawdekar, M.G. Liquid phase hydrogenation of cinnamaldehyde over supported ruthenium catalysts: Influence of particle size, bimetallics and nature of support. J. Mol. Catal. 1993, 85, 215-228.

46. Giroir-Fendler, A.; Richard, D.; Gallezot, P. Chemioselectivity in the catalytic hydrogenation of cinnamaldehyde. Effect of metal particle morphology. Catal. Lett. 1990, 5, 175-181.

47. Plomp, A.J.; Vuori, H.; Krause, A.O.; de Jong, K.P.; Bitter, J.H. Particle size effects for carbon nanofiber supported platinum and ruthenium catalysts for the selective hydrogenation of cinnamaldehyde. Appl. Catal. A 2008, 351, 9-15.

48. Neri, G.; Milone, C.; Donato, A.; Mercadante, L.; Visco, A.M. Selective Hydrogenation of Citral Over Pt-Sn Supported on Activated Carbon. J. Chem. Technol. Biotechnol. 1994, 60, 83-88.

49. Neri, G.; Mercadante, L.; Milone, C.; Pietropaolo, R.; Galvagno, S. Hydrogenation of citral and cinnamaldehyde over bimetallic $\mathrm{Ru}-\mathrm{Me} / \mathrm{Al}_{2} \mathrm{O}_{3}$ catalysts. J. Mol. Catal. A 1996, 108, 41-50.

50. Ponec, V. On the role of promoters in hydrogenations on metals; $\alpha, \beta$-unsaturated aldehydes and ketones. Appl. Catal. A 1997, 149, 27-48.

51. Barbaro, P.; Liguori, F. Heterogenized Homogeneous Catalysts for Fine Chemicals Production: Materials and Processes; Springer: London, UK, 2010.

52. Claus, P.; Önal, Y. Regioselective hydrogenations. Handbook of Heterogeneous Catalysis. In Handbook of Heterogeneous Catalysis, 2nd ed.; Ertl, G., Knözinger, H., Schüth, F., Weitkamp, J., Eds.; WILEY-VCH: Weinheim, Germany, 2008; pp. 3311-3312. 
53. Vannice, A.; Singh, U.K. Citral hydrogenation over Pt and other group VIII metals. Abstr. Pap. Amer. Chem. Soc. 2002, 223, 437-437.

54. Delbecq, F.; Sautet, P. A density functional study of adsorption structures of unsaturated aldehydes on Pt(III): a key factor for hydrogenation Selectivity. J. Catal. 2002, 211, 398-406.

55. Claus, P. Selective hydrogenation of $\alpha, \beta$-unsaturated aldehydes and other $\mathrm{C}=\mathrm{O}$ and $\mathrm{C}=\mathrm{C}$ bonds containing compounds. Topic. Catalysis 1998, 5, 51-62.

56. Ekou, T.; Vicente, A.; Lafaye, G.; Especel, C.; Marecot, P. Bimetallic Rh-Ge and Pt-Ge catalysts supported on $\mathrm{TiO}_{2}$ for citral hydrogenation II. Catalytic properties. Appl. Catal. A 2006, 314, 73-80.

57. Delbecq, F.; Sautet, P. Competitive $\mathrm{C}=\mathrm{C}$ and $\mathrm{C}=\mathrm{O}$ Adsorption of $\alpha, \beta$-Unsaturated Aldehydes on Pt and Pd Surfaces in Relation with the Selectivity of Hydrogenation Reactions: A Theoretical Approach. J. Catal. 1995, 152, 217-236.

58. Maki-Arvela, P.; Tiainen, L.P.; Neyestanaki, A.K.; Sjoholm, R.; Rantakyla, T.K.; Laine, E.; Salmi, T.; Murzin, D.Y. Liquid phase hydrogenation of citral: Suppression of side reactions. Appl. Catal. A 2002, 237, 181-200.

59. Hájek, J.; Kumar, N.; Mäki-Arvela, P.; Salmi, T.; Murzin, D.Y.; Paseka, I.; Heikkilä, T.; Laine, E.; Laukkanen, P.; Väyrynen, J. Ruthenium-modified MCM-41 mesoporous molecular sieve and Y zeolite catalysts for selective hydrogenation of cinnamaldehyde. Appl. Catal. A 2003, 251, 385-396.

60. Berty, T.E.; Reamer, H.H.; Sage, B.H. Phase behavior in the hydrogen-cyclohexane system. $J$. Chem. Eng. Data 1966, 11, 25-30.

61. Kun, I.; Szöllösi, G.; Bartók, M. Crotonaldehyde hydrogenation over clay-supported platinum catalysts. J.Mol. Catal. A 2001, 169, 235-246.

62. Yamada, H.; Goto, S. The effect of solvents polarity on selective hydrogenation of unsaturated aldehyde in gas-liquid-solid three phase reactor. J. Chem. Eng. Jpn. 2003, 36, 586-589.

63. Burgener, M.; Furrer, R.; Mallat, T.; Baiker, A. Hydrogenation of citral over Pd/alumina: comparison of "supercritical" $\mathrm{CO}_{2}$ and conventional solvents in continuous and batch reactors. Appl. Catal. A 2004, 268, 1-8.

64. Zhao, F.; Fujita, S.i.; Akihara, S.; Arai, M. Hydrogenation of benzaldehyde and cinnamaldehyde in compressed $\mathrm{CO}_{2}$ medium with a pt/c catalyst: A study on molecular interactions and pressure effects. J. Phys. Chem. A 2005, 109, 4419-4424.

65. Liu, R.; Zhao, F.; Fujita, S.i.; Arai, M. Selective hydrogenation of citral with transition metal complexes in supercritical carbon dioxide. Appl. Catal. A 2007, 316, 127-133.

66. Jiang, H.J.; Jiang, H.B.; Zhu, D.M.; Zheng, X.L.; Fu, H.Y.; Chen, H.; Li, R.X. Cooperation between the surface hydroxyl groups of the support and organic additives in the highly selective hydrogenation of citral. Appl. Catal. A 2012, 445-446, 351-358.

67. Fujita, S.i.; Sano, Y.; Bhanage, B.M.; Arai, M. Supported liquid-phase catalysts containing ruthenium complexes for selective hydrogenation of $\alpha, \beta$-unsaturated aldehyde: Importance of interfaces between liquid film, solvent, and support for the control of product selectivity. J. Catal. 2004, 225, 95-104. 
68. Strohmeier, W.; Graser, B.; Mar-çec, R.; Holke, K. Comparison of the activity of homogeneous catalysts in liquid phase without solvent and as supported liquid phase catalysts (SLPC). J. Mol. Catal. 1981, 11, 257-262.

69. Sokolskii, D.; Anisimova, N.; Zharmagambetova, A.; Mukhamedzhanova, S.; Edygenova, L. $\mathrm{Pt}-\mathrm{Fe}_{2} \mathrm{O}_{3}$ catalytic system for hydrogenation reactions. React. Kinet. Catal. Lett. 1987, 33, 399-403.

70. Sokolskii, D.V.; Pak, A.M.; Ginzburg, M.A.; Vozdvizhenskii, V.F. Hydrogenation of citral on group-VIII metals. Dokl. Akad. Nauk Sssr 1978, 239, 897-900.

71. Sautet, P. Theoretical chemistry as a tool for interpreting catalysts selectivities. Topic. Catal. 2000, 13, 213-219.

72. Davis, J.L.; Barteau, M.A. Vinyl substituent effects on the reactions of higher oxygenates on Pd(111). J. Mol. Catal. 1992, 77, 109-124.

73. Fadley, C.S.; Shirley, D.A. Electronic Density of States. Proceedings of the Third Materials Research Symposium, Gaithersburg, MD, USA. 1969.

74. Manikandan, D.; Divakar, D.; Sivakumar, T. Selective hydrogenation of citral over noble metals intercalated montmorillonite catalysts. Catal. Lett. 2008, 123, 107-114.

75. Ekou, T.; Ekou, L.; Vicente, A.; Lafaye, G.; Pronier, S.; Especel, C.; Marecot, P. Citral hydrogenation over $\mathrm{Rh}$ and $\mathrm{Pt}$ catalysts supported on $\mathrm{TiO}_{2}$ : Influence of the preparation and activation protocols of the catalysts. J. Mol. Catal. A 2011, 337, 82-88.

76. Vicente, A.; Ekou, T.; Lafaye, G.; Especel, C.; Marecot, P.; Williams, C.T. Influence of the nature of the precursor salts on the properties of $\mathrm{Rh}-\mathrm{Ge} / \mathrm{TiO} \mathrm{O}_{2}$ catalysts for citral hydrogenation. $J$. Catal. 2010, 275, 202-210.

77. Sordelli, L.; Psaro, R.; Vlaic, G.; Cepparo, A.; Recchia, S.; Dossi, C.; Fusi, A.; Zanoni, R. EXAFS studies of supported Rh-Sn catalysts for citral hydrogenation. J. Catal. 1999, 182, 186-198.

78. Ananthan, S.A.; Narayanan, V. Liquid Phase Selective Hydrogenation of Citral over Ru/Tio ${ }_{2}$ and $\mathrm{Pt}_{\mathrm{Tio}} \mathrm{N}_{2}$ Nano Catalysts. Proceedings of the International Conference on Nanoscience, Engineering and Technology, athyabama University, Chennai, Tamilnadu, India, November 2011; pp. 23-29.

79. Mukherjee, S.; Vannice, M.A. Solvent effects in liquid-phase reactions: I. Activity and selectivity during citral hydrogenation on $\mathrm{Pt} / \mathrm{SiO}_{2}$ and evaluation of mass transfer effects. J. Catal. 2006, 243, 108-130.

80. Diaz, G.; Gomez-Cortes, A.; Hernandez-Cristobal, O.; Murcia, J.J.; Borda, G.; Rojas, H. Hydrogenation of citral over irau/tio 2 catalysts. effect of the preparation method. Topic. Catal. 2011, 54, 467-473.

81. Rojas, H.; Borda, G.; Reyes, P.; Martinez, J.J.; Valencia, J.; Fierro, J.L.G. Citral hydrogenation over $\mathrm{Ir} / \mathrm{TiO}_{2}$ and $\mathrm{Ir} / \mathrm{TiO}_{2} / \mathrm{SiO}_{2}$ catalysts. Catal. Today 2008, 133, 699-705.

82. Borda, G.; Rojas, H.; Murcia, J.; Fierro, J.L.G.; Reyes, P.; Oportus, M. Hydrogenation of citral on $\mathrm{Ir} / \mathrm{SiO}_{2}$ catalysts. Effect of the addition of $\mathrm{Nb}_{2} \mathrm{O}_{5}$ on surface and catalytic properties. React. Kinet. Catal. Lett. 2007, 92, 369-376.

83. Reyes, P.; Rojas, H.; Pecchi, G.; Fierro, J.L.G. Liquid-phase hydrogenation of citral over Ir-supported catalysts. J. Mol. Catal. A 2002, 179, 293-299. 
84. Bertero, N.M.; Trasarti, A.F.; Moraweck, B.; Borgna, A.; Marchi, A.J. Selective liquid-phase hydrogenation of citral over supported bimetallic Pt-Co catalysts. Appl. Catal. A 2009, 358, 32-41.

85. Liu, R.X.; Zhao, F.Y. Selective hydrogenation of citral over Au-based bimetallic catalysts in supercritical carbon dioxide. Sci. China Chem. 2010, 53, 1571-1577.

86. Silva, A.M.; Santos, O.A.A.; Mendes, M.J.; Jordao, E.; Fraga, M.A. Hydrogenation of citral over ruthenium-tin catalysts. Appl. Catal. A 2003, 241, 155-165.

87. Vicente, A.; Lafaye, G.; Especel, C.; Marecot, P.; Williams, C.T. The relationship between the structural properties of bimetallic $\mathrm{Pd}-\mathrm{Sn} / \mathrm{SiO}_{2}$ catalysts and their performance for selective citral hydrogenation. J.Catal. 2011, 283, 133-142.

88. Tiainen, L.P.; Maki-Arvela, P.; Salmi, T. Modelling of citral hydrogenation kinetics on an $\mathrm{Ni} / \mathrm{Al}_{2} \mathrm{O}_{3}$ catalyst. Catal. Today 1999, 48, 57-63.

89. Pak, A.M.; Konuspaev, S.R.; Zakumbaeva, G.D.; Sokolskii, D.V. Hydrogenation of Citral to Citronellol Over Ni-Cr $\mathrm{O}_{3}$. React. Kinet. Catal. Lett. 1981, 16, 339-343.

90. Asedegbega-Nieto, E.; Bachiller-Baeza, B.; Guerrero-Ruiz, A.; Rodríguez-Ramos, I. Modification of catalytic properties over carbon supported $\mathrm{Ru}-\mathrm{Cu}$ and $\mathrm{Ni}-\mathrm{Cu}$ bimetallics: I. Functional selectivities in citral and cinnamaldehyde hydrogenation. Appl. Catal. A 2006, 300, 120-129.

91. Pérez-Cadenas, A.F.; Zieverink, M.M.P.; Kapteijn, F.; Moulijn, J.A. High performance monolithic catalysts for hydrogenation reactions. Catal. Today 2005, 105, 623-628.

92. Pérez-Cadenas, A.F.; Kapteijn, F.; Zieverink, M.M.P.; Moulijn, J.A. Selective hydrogenation of fatty acid methyl esters over palladium on carbon-based monoliths: Structural control of activity and selectivity. Catal. Today 2007, 128, 13-17.

93. Galvagno, S.; Milone, C.; Donate, A.; Neri, G.; Pietropaolo, R. Influence of metal particle size in the hydrogenation of citral over Ru/C. Catal. Lett. 1993, 18, 349-355.

94. Galvagno, S.; Milone, C.; Neri, G.; Donato, A.; Pietropaolo, R. Hydrogenation of cinnamaldehyde and citral over ru supported catalysts. Stud. Surf. Sci. Catal. 1993, 78, 163-170.

95. Neri, G.; Milone, C.; Galvagno, S.; Pijpers, A.P.J.; Schwank, J. Characterization of Pt-Sn/carbon hydrogenation catalysts. Appl. Catal. A 2002, 227, 105-115.

96. Serrano-Ruiz, J.C.; Sepulveda-Escribano, A.; Rodriguez-Reinoso, F.; Duprez, D. Pt-Sn catalysts supported on highly-dispersed ceria on carbon-Application to citral hydrogenation. J. Mol. Catal. A 2007, 268, 227-234.

97. Vilella, I.M.; Borbath, I.; Somodi, F.; Margitfalvi, J.L.; de Miguel, S.R.; Scelza, O.A. The influence of the preparation method on the behaviour of PtGe catalysts supported on activated carbon in citral hydrogenation. Catal. Lett. 2008, 125, 254-263.

98. Vilella, I.M.J.; de Miguel, S.R.; Scelza, O.A. Hydrogenation of citral on Pt and PtSn supported on activated carbon felts (ACF). Latin Amer. Appl. Res. 2005, 35, 51-57.

99. Vilella, I.M.J.; de Miguel, S.R.; Scelza, O.A. Pt, PtSn and PtGe catalysts supported on granular carbon for fine chemistry hydrogenation reactions. J. Mol. Catal. A 2008, 284, 161-171. 
100. Vilella, I.M.J.; Miguel, S.R.; Salinas-Martínez de Lecea, C.; Linares-Solano, Á.; Scelza, O.A. Catalytic performance in citral hydrogenation and characterization of PtSn catalysts supported on activated carbon felt and powder. Appl. Catal. A 2005, 281, 247-258.

101. Aumo, J.; Oksanen, S.; Mikkola, J.P.; Salmi, T.; Murzin, D.Y. Hydrogenation of citral over activated carbon cloth catalyst. Ind. Eng. Chem. Res. 2005, 44, 5285-5290.

102. Aumo, J.; Oksanen, S.; Mikkola, J.P.; Salmi, T.; Murzin, D.Y. Novel woven active carbon fiber catalyst in the hydrogenation of citral. Catal. Today 2005, 102, 128-132.

103. Giroir-Fendler, A.; Richard, D.; Gallezot, P. Selectivity in cinnamaldehyde hydrogenation of group-viii metals supported on graphite and carbon. Stud. Surf. Sci. Catal. 1988, 41, 171-178.

104. Steffan, M.; Klasovsky, F.; Arras, J.; Roth, C.; Radnik, J.; Hofmeister, H.; Claus, P. Carbon-carbon double bond versus carbonyl group hydrogenation: Controlling the intramolecular selectivity with polyaniline-supported platinum catalysts. Adv. Synth. Catal. 2008, 350, 1337-1348.

105. Gallezot, P.; Richard, D. Selective Hydrogenation of $\alpha, \beta$-Unsaturated Aldehydes. Catal. Rev. 1998, 40, 81-126.

106. Bachiller-Baeza, B.; Guerrero-Ruiz, A.; Wang, P.; Rodríguez-Ramos, I. Hydrogenation of citral on activated carbon and high-surface-area graphite-supported ruthenium catalysts modified with iron. J. Catal. 2001, 204, 450-459.

107. Court, J.; Jablonski, J.; Hamarthibault, S. Hydrogenation of citral in the liquid-phase over new bimetallic Ni-M catalysts supported on graphite. Stud. Surf. Sci. Catal. 1993, 78, 155-162.

108. Cerro-Alarcón, M.; Bachiller-Baeza, B.; Guerrero-Ruiz, A.; Rodríguez-Ramos, I. Effect of the reduction-preparation method on the surface states and catalytic properties of supported-nickel particles. J. Mol. Catal. A 2006, 258, 221-230.

109. Zhao, Y.; Zhang, H.; Huang, C.; Chen, S.; Yu, B.; Xu, J.; Liu, Z. Pd nanoparticles immobilized on graphite oxide modified with a base: Highly efficient catalysts for selective hydrogenation of citral. Sci. China Chem. 2013, 56, 203-209.

110. Satagopan, V.; Chandalia, S.B. Selectivity aspects in the multiphase hydrogenation of alpha, beta-unsaturated aldehydes over supported noble-metal catalysts 1. J. Chem. Technol. Biotechnol. 1994, 59, 257-263.

111. Tin, K.C.; Wong, N.B.; Li, R.X.; Li, Y.Z.; Li, X.J. Studies on catalytic hydrogenation of citral by water-soluble palladium complex. J. Mol. Catal. A 1999, 137, 113-119.

112. Yang, Q.H.; Hou, P.X.; Bai, S.; Wang, M.Z.; Cheng, H.M. Adsorption and capillarity of nitrogen in aggregated multi-walled carbon nanotubes. Chem. Phys. Lett. 2001, 345, 18-24.

113. Nhut, J.M.; Pesant, L.; Tessonnier, J.P.; Winé, G.; Guille, J.; Pham-Huu, C.; Ledoux, M.J. Mesoporous carbon nanotubes for use as support in catalysis and as nanosized reactors for one-dimensional inorganic material synthesis. Appl. Catal. A 2003, 254, 345-363.

114. Li, Y.; Lai, G.H.; Zhou, R.X. Carbon nanotubes supported Pt-Ni catalysts and their properties for the liquid phase hydrogenation of cinnamaldehyde to hydrocinnamaldehyde. Appl. Surf. Sci. 2007, 253, 4978-4984.

115. Ma, H.; Wang, L.; Chen, L.; Dong, C.; Yu, W.; Huang, T.; Qian, Y. Pt nanoparticles deposited over carbon nanotubes for selective hydrogenation of cinnamaldehyde. Catal. Commun. 2007, 8 , $452-456$. 
116. Abbaslou, R.M.M.; Tavassoli, A.; Soltan, J.; Dalai, A.K. Iron catalysts supported on carbon nanotubes for Fischer-Tropsch synthesis: Effect of catalytic site position. Appl. Catal. A 2009, $367,47-52$.

117. Bligaard, T. Linear energy relations and the computational design of selective hydrogenation/dehydrogenation catalysts. Angew. Chem. Int. Ed. 2009, 48, 9782-9784.

118. Asedegbega-Nieto, E.; Guerrero-Ruiz, A.; Rodríguez-Ramos, I. Modification of the stereo selectivity in the citral hydrogenation by application of carbon nanotubes as support of the $\mathrm{Pt}$ particles. Carbon 2006, 44, 804-806.

119. Qin, F.; Shen, W.; Wang, C.C.; Xu, H.L. Selective hydrogenation of citral over a novel platinum/MWNTs nanocomposites. Catalysis Communications 2008, 9, 2095-2098.

120. Guo, G.Q.; Qin, F.; Yang, D.; Wang, C.C.; Xu, H.L.; Yang, S. Synthesis of platinum nanoparticles supported on poly(acrylic acid) grafted MWNTs and their hydrogenation of citral. Chem. Mater. 2008, 20, 2291-2297.

121. Zgolicz, P.D.; Stassi, J.P.; Yañez, M.J.; Scelza, O.A.; de Miguel, S.R. Influence of the support and the preparation methods on the performance in citral hydrogenation of Pt-based catalysts supported on carbon nanotubes. J. Catal. 2012, 290, 37-54.

122. Ananthan, S.A.; Vengidusamy, N.; Giribabu, K.; Suresh, R. Carbon nanotunes supported Pt and $\mathrm{Pt}-\mathrm{Ru}$ catalysts for selective hydrogenation of citral: Effect of promoters and thermal activation of catalysts. Adv. Mater. Res. 2012, 584, 229-233.

123. Ananthan, S.A.; Narayanan, V. MWCNT supported Pt-Au nanocatalysts for liquid phase selective hydrogenation of citral. Int. J.Modern Chem. 2012, 1, 45-58.

124. Bachiller-Baeza, B.; Rodríguez-Ramos, I.; Guerrero-Ruiz, A. Influence of $\mathrm{Mg}$ and Ce addition to ruthenium based catalysts used in the selective hydrogenation of alpha,beta-unsaturated aldehydes. Appl. Catal. A 2001, 205, 227-237.

125. Zhu, J.; Lu, M.H.; Li, M.S.; Zhu, J.J.; Shan, Y.H. Selective Hydrogenation of citral over a carbon-titania composite supported palladium catalyst. Chinese J. Chem. 2011, 29, 655-660.

126. Zhu, J.; Li, M.; Lu, M. Synthesis of carbon nanofiber-titania-cordierite monolith composite and its application as catalyst support on citral hydrogenation. Adv. Mater. Res. 2012, 535-537, 178-185.

127. Zhu, J.; Lu, M.; Li, M.; Zhu, J.; Shan, Y. Synthesis of carbon-titania composite and its application as catalyst support. Mater. Chem. Phys. 2012, 132, 316-323.

128. Ananthan, S.A.; Narayanan, V. Liquid-Phase Hydrogenation of citral over $\mathrm{Pt} / \mathrm{TiO}_{2}$ and Pt-Fe/TiO 2 catalysts. Asian J. Chem. 2011, 23, 183-188.

129. Li, D.; Ichikuni, N.; Shimazu, S.; Uematsu, T. Hydrogenation of $\mathrm{CO}_{2}$ over sprayed $\mathrm{Ru} / \mathrm{TiO}$ fine particles and strong metal support interaction. Appl. Catal. A 1999, 180, 227-235.

(C) 2013 by the authors; licensee MDPI, Basel, Switzerland. This article is an open access article distributed under the terms and conditions of the Creative Commons Attribution license (http://creativecommons.org/licenses/by/3.0/). 